\title{
Observations and comparisons of cloud microphysical properties in spring and summertime Arctic stratocumulus clouds during the ACCACIA campaign
}

\author{
G. Lloyd ${ }^{1}$, T. W. Choularton ${ }^{1}$, K. N. Bower ${ }^{1}$, J. Crosier $^{1}$, H. Jones ${ }^{1}$, J. R. Dorsey ${ }^{1}$, M. W. Gallagher ${ }^{1}$, P. Connolly ${ }^{1}$, \\ A. C. R. Kirchgaessner ${ }^{2}$, and T. Lachlan-Cope ${ }^{2}$ \\ ${ }^{1}$ Centre for Atmospheric Science, University of Manchester, Manchester, UK \\ ${ }^{2}$ British Antarctic Survey, NERC, High Cross, Madingley Rd, Cambridge CB3 OET, UK
}

Correspondence to: G. Lloyd (gary.lloyd@ manchester.ac.uk)

Received: 1 September 2014 - Published in Atmos. Chem. Phys. Discuss.: 19 November 2014

Revised: 25 February 2015 - Accepted: 11 March 2015 - Published: 2 April 2015

\begin{abstract}
Measurements from four case studies in spring and summer-time Arctic stratocumulus clouds during the Aerosol-Cloud Coupling And Climate Interactions in the Arctic (ACCACIA) campaign are presented. We compare microphysics observations between cases and with previous measurements made in the Arctic and Antarctic. During ACCACIA, stratocumulus clouds were observed to consist of liquid at cloud tops, often at distinct temperature inversions. The cloud top regions precipitated low concentrations of ice into the cloud below. During the spring cases median ice number concentrations $\left(\sim 0.5 \mathrm{~L}^{-1}\right)$ were found to be lower by about a factor of 5 than observations from the summer campaign $\left(\sim 3 \mathrm{~L}^{-1}\right)$. Cloud layers in the summer spanned a warmer temperature regime than in the spring and enhancement of ice concentrations in these cases was found to be due to secondary ice production through the Hallett-Mossop $(\mathrm{H}-\mathrm{M})$ process. Aerosol concentrations during spring ranged from $\sim 300-400 \mathrm{~cm}^{-3}$ in one case to lower values of $\sim 50$ $100 \mathrm{~cm}^{-3}$ in the other. The concentration of aerosol with sizes $D_{\mathrm{p}}>0.5 \mu \mathrm{m}$ was used in a primary ice nucleus (IN) prediction scheme (DeMott et al., 2010). Predicted IN values varied depending on aerosol measurement periods but were generally greater than maximum observed median values of ice crystal concentrations in the spring cases, and less than the observed ice concentrations in the summer due to the influence of secondary ice production. Comparison with recent cloud observations in the Antarctic summer (Grosvenor et al., 2012), reveals lower ice concentrations in Antarctic clouds in comparable seasons. An enhancement of ice crystal
\end{abstract}

number concentrations (when compared with predicted IN numbers) was also found in Antarctic stratocumulus clouds spanning the $\mathrm{H}-\mathrm{M}$ temperature zone; however, concentrations were about an order of magnitude lower than those observed in the Arctic summer cases but were similar to the peak values observed in the colder Arctic spring cases, where the $\mathrm{H}-\mathrm{M}$ mechanism did not operate.

\section{Introduction}

The Arctic is a region that has experienced rapid climate perturbation in recent decades, with warming rates there being almost twice the global average over the past 100 years (ACIA, 2005; IPCC, 2007). The most striking consequence of this warming has been the decline in the extent and area of sea ice, especially in the warm season. The lowest sea ice extent and area on record were both observed on 13 September 2012 (Parkinson and Comiso, 2013) and despite some uncertainty ice-free Arctic summers could become a reality by 2030 (Overland and Wang, 2013). The underlying warming is very likely caused by increasing anthropogenic greenhouse gases and Arctic amplification, which is a wellestablished feature of global climate models (GCMs; see for example IPCC 5th Assessment Report, 2014). However, the details of Arctic climate are complex with interactions between the atmospheric boundary layer, clouds, overlying sea ice and water leading to a number of feedback mechanisms. These interactions are not well understood due to variabil- 
ity in the spatial and temporal extent of feedback mechanisms, and the fact that those that are included in GCMs may not be accurately parameterised (Callaghan et al., 2012). Clouds play an important role in a number of proposed feedback processes that may be active in the Arctic (Curry et al., 1996; Walsh et al., 2009), Arctic clouds are the dominant factor controlling the surface energy budget, producing a mostly positive forcing throughout the year, apart from a brief cooling period during the middle of summer (Intrieri, 2002). These clouds affect both the long-wave (year-round) and short-wave (summer-only) radiation budgets and influence turbulent surface exchange. Cloud microphysical influence on cloud radiative properties depends on the amount of condensed water and the size, phase and habit of the cloud particles (Curry et al., 1996). These factors are controlled in part by the cloud condensation nuclei (CCN) and ice nuclei (IN) concentrations and properties.

The impact of CCN and IN on cloud properties is significant. A number of hypothesis explain how variation in the availability of $\mathrm{CCN}$ and IN may go on to alter microphysical structure. Firstly the thermodynamic indirect effect describes how an increase in CCN leads to a reduction in droplet size, inhibiting the development of drizzle needed for rime splintering, reducing the efficiency of the process, which may have a significant impact on cloud glaciation around $-5^{\circ} \mathrm{C}$. Secondly the glaciation indirect effect states that an increase in IN leads to an increase in the number of ice crystals. Finally the riming indirect effect inhibits ice mass growth as increasing CCN leads to smaller drops with lower collection efficiencies that reduces the riming rate (Lohmann and $\mathrm{Fe}$ ichter, 2005).

In relation to these three hypotheses there have been a range of results presented in the literature in recent years investigating the impact of aerosol on Arctic clouds. For example, Lance et al. (2011) presented aircraft data from the Arctic mixed-phase clouds gathered in the Alaska region from the Aerosol, Radiation, and Cloud Processes affecting Arctic Climate (ARCPAC) experiment. They reported that the concentration of ice particles greater than $400 \mu \mathrm{m}$ is correlated with the concentration of droplets larger than $30 \mu \mathrm{m}$, providing support for the riming indirect effect. They found that mixed-phase clouds in polluted conditions with a high aerosol population due to long-range transported biomass burning aerosol contained a narrower droplet size distribution and 1-2 orders of magnitude fewer precipitating ice particles than clean clouds at the same temperature. Although this finding is not consistent with the glaciation indirect it is likely due to the increase in aerosol not providing active IN in clouds over the temperature range that was investigated.

Jackson et al. (2012) presented data from the Indirect and Semi-Direct Aerosol Campaign (ISDAC) and from the Mixed-Phase Arctic Cloud Experiment. They found no evidence for a riming-indirect effect but did find a correlation between ice crystal number concentration and above-cloud aerosol concentration in this case. This finding, together with sub-adiabatic liquid water contents suggested that ice nuclei were being entrained from above cloud top in their studies, which is consistent with the glaciation indirect effect. They also reported lower ice crystal number concentrations and lower effective radius in more polluted cases compared to data collected in cleaner single-layer stratocumulus conditions during the Mixed-Phase Arctic Cloud Experiment (MPACE) (Verlinde et al., 2007), which is consistent with the operation of the thermodynamic indirect effect. They concluded that a wider range of Arctic clouds need to be studied to investigate the generality of their results.

A paucity of observations in the Arctic means that neither the aerosol processes, nor cloud properties are well understood or accurately represented within models, with the result that aerosol and cloud-forcing of Arctic climate is poorly constrained. An important aspect of modelling Arctic clouds is the use of primary IN parameterisations to initiate the ice phase in these clouds. The measurements made in this study of both aerosol properties and ice number concentrations allowed us to compare predicted ice nuclei concentrations from the DeMott et al. (2010) IN parameterisation and cloud ice concentrations measured by microphysics probes.

In the Arctic lower troposphere low cloud dominates the variability in Arctic cloud cover (Curry et al., 1996), with temperature and humidity profiles showing a high frequency of one or more temperature inversions (Kahl, 1990) below which stratocumulus clouds form. During the Arctic summer, therefore, these low clouds often consist of multiple layers, with a number of theories describing their vertical separation (Herman and Goody, 1976; Tsay and Jayaweera, 1984; McInnes and Curry, 1995). Such cloud layers have been observed during different seasons but the relationship between temperature and the formation of ice in them is not well understood. Jayaweera and Ohtake (1973) observed very little ice above $-20^{\circ} \mathrm{C}$, but Curry et al. (1997) observed ice to be present in clouds at temperatures $(T)$ between -8 and $-14{ }^{\circ} \mathrm{C}$ during the Beaufort Arctic Storms Experiment (BASE). It is possible that the large variation in temperature at which glaciation is observed is caused by changes in the concentration and composition of aerosol (Curry, 1995). Recent work, such as in the Arctic Cloud Experiment (ACE) (Uttal et al., 2002) has improved our knowledge of Arctic mixed-phase clouds, which dominate in the coldest 9 months of the Arctic year. ACE reported that clouds were mainly comprised of liquid tops, tended to be very long lived and continually precipitated ice. The longevity of these clouds might be considered unusual as the formation of ice leads to loss of water through the Wegener-Bergeron-Findeison process. More recently, the M-PACE investigated the Arctic autumn transition season on the north slope of Alaska, in the area to the east of Barrow. Again, predominantly mixedphase clouds were observed with liquid layers present at temperatures as low as $-30^{\circ} \mathrm{C}$. Here we present detailed airborne microphysical and aerosol measurements made in stratocumulus cloud regions in the European Arctic during the 
recent Aerosol-Cloud Coupling And Climate Interactions in the Arctic (ACCACIA) campaigns. We present data from two aircraft during early spring, in March and April 2013, and from a single aircraft during the following Arctic summer, in July 2013

The objectives of this paper are

1. to report the microphysics and cloud particle properties of Arctic clouds and the properties, number and size distributions of aerosols in the vicinity of these;

2. to identify the origin of the ice phase in these clouds and to compare ice crystal number concentrations with the parameterisation of primary IN concentrations of DeMott et al. (2010);

3. to compare the cloud physics in spring and summer conditions and to identify any contributions of secondary ice particle production;

4. to compare and contrast the mixed-phase cloud microphysics of Arctic clouds with clouds observed in the Antarctic.

\section{Methodology}

The ACCACIA campaigns took place during March-April and July 2013. They were conducted in the region between Greenland and Norway mainly in the vicinity of Svalbard. The overarching theme of the project was to reduce the large uncertainty in the effects of aerosols and clouds on the Arctic surface energy balance and climate. Key to the work presented here is an understanding of the microphysical properties of Arctic clouds and their dependence on aerosol properties. To this end, the FAAM (Facility for Airborne Atmospheric Measurements) BAe-146 (British Aerospace-146, or 146) aircraft performed a number flights incorporating profiled ascents, descents and constant altitude runs below, within and above cloud during the spring period. This provided high-resolution measurements of the vertical structure of the cloud microphysics and the aerosol properties in and out of cloud regions. The British Antarctic Survey (BAS) Twin Otter aircraft flew during both campaign periods, providing a subset of the BAe-146 measurements. It was the only aircraft present during the summer period. A total of 9 science flights were conducted during the spring period with complementary flights from the BAS twin otter and 6 flights by the BAS twin otter alone during the summer period.

Two case studies are selected from both the early spring and summer campaigns. The spring campaign case studies were selected for having quite different aerosol loadings within the boundary layer. One was in relatively clean Arctic air with low total aerosol numbers, while the second had higher aerosol loadings in the boundary layer. Summer flight cases were selected for being the cases with higher cloud layer temperatures in a range suitable for secondary ice production through the Hallett-Mossop Process (Hallett and Mossop, 1974) to take place. This process is known to operate under particular conditions, and so could greatly enhance ice crystal number concentrations. Temperature profiles in the spring cases revealed stratocumulus cloud temperatures generally between $-10^{\circ} \mathrm{C}<T<-20^{\circ} \mathrm{C}$, outside of the $\mathrm{H}-$ M zone.

\subsection{Instrumentation}

Instrumentation onboard the FAAM BAe-146 aircraft used for making measurements of the cloud and aerosol microphysics reported in this paper included the Cloud Imaging Probe models 15 and 100 (CIP-15 and CIP-100, Droplet Measurement Technologies (DMT), Boulder, USA) (Baumgardner et al., 2001), the Cloud Droplet Probe (CDP-100 Version 2, DMT) (Lance et al., 2010) and the Two-Dimensional Stereoscopic Probe (2D-S, Stratton Park Engineering Company Inc. Boulder, USA) (Lawson, 2006). The CIP-15 and CIP-100 are optical array shadow probes consisting of 64element photodiode arrays providing image resolutions of 15 and $100 \mu \mathrm{m}$, respectively. The 2D-S is a higher-resolution optical array shadow probe which consists of a 128-element photodiode array with image resolution of $10 \mu \mathrm{m}$. The CDP measures the liquid droplet size distribution over the particle size range of $3<d_{\mathrm{p}}<50 \mu \mathrm{m}$. The intensity of forward scattered laser light in the range $4-12^{\circ}$ is collected and particle diameter calculated from this information using Mie scattering solutions (Lance et al., 2010).

A Cloud Aerosol Spectrometer (CAS, DMT) and a Passive Cavity Aerosol Spectrometer Probe (PCASP-100X, DMT) were both used to measure aerosol size distributions onboard the 146. The CAS measures particles in the size range of $0.51<d_{\mathrm{p}}<50 \mu \mathrm{m}$ using forward scattered light from single particles in the $4-13^{\circ}$ range and backscattered light in the $5-13^{\circ}$ range. Particle size can be determined from both the forward- and back-scattered light intensity using Mie scattering solutions (Baumgardner et al., 2001). The PCASP is another optical particle counter (OPC) and measures aerosol particles in the size range of $0.1<d_{\mathrm{p}}<3 \mu \mathrm{m}$. In this instrument, particles are sized through measurement of the intensity of laser light scattered within the $35-120^{\circ}$ range (Rosenberg et al., 2012). All the above instruments were mounted externally on the FAAM aircraft. Examples of additional core data measurements that were also used in this paper include temperature (Rosemount/Goodrich type 102 temperature sensors) and altitude measured by the GPS-aided Inertial Navigation system (GIN).

Instrumentation onboard the Twin Otter Meteorological Airborne Science INstrumentation (MASIN) aircraft, relevant to measurements reported in this paper included a CDP100 for drop size distributions and a 2D-S (summer only), both similar to those on the FAAM aircraft; a CIP-25 (as on FAAM except consisting of a 64-element photodiode array providing an image resolution of $25 \mu \mathrm{m}$ ) and core data 
Table 1. Flight numbers, run numbers, and their associated time intervals, altitude and temperature range for the four ACCACIA case studies presented.

\begin{tabular}{lllll}
\hline Flight & $\begin{array}{l}\text { Run } \\
\text { number }\end{array}$ & Time (UTC) & Altitude $(\mathrm{m})$ & $\begin{array}{l}\text { Temperature } \\
\left({ }^{\circ} \mathrm{C}\right)\end{array}$ \\
\hline B761 & A1 & $13: 13: 26-13: 16: 43$ & $1850-50$ & -19 to -5 \\
B761 & A2 & $13: 04: 40-13: 10: 33$ & $300-1850$ & -8 to -19 \\
B761 & A3 & $13: 23: 20-13: 33: 19$ & $1700-50$ & -19 to -7 \\
\hline B768 & B1 & $11: 45: 16-11: 54: 02$ & $1600-50$ & -17 to -9 \\
B768 & B2 & $11: 38: 39-11: 44: 59$ & $50-1600$ & -17 to -4 \\
B768 & B3 & $12: 01: 30-12: 19: 08$ & $400-50$ & -12 to -9 \\
B768 & B4 & $12: 32: 20-12: 48: 14$ & $1300-1050$ & -16 to -14 \\
\hline M191 & C1.1 & $08: 53: 45-09: 00: 00$ & $\sim 2950$ & $\sim-7$ \\
M191 & C1.2 & $09: 00: 00-09: 06: 50$ & $\sim 2900$ & $\sim-6$ \\
M191 & C1.3 & $09: 06: 50-09: 13: 35$ & $\sim 2750$ & $\sim-5$ \\
M191 & C1.4 & $09: 13: 35-09: 21: 09$ & $2750-2250$ & -4 to -2 \\
M191 & C2 & $10: 14: 58-10: 33: 51$ & $3350-2300$ & -7 to -3 \\
\hline M192 & D1 & $12: 58: 58-13: 06: 02$ & $3100-3750$ & -5 to -1 \\
M192 & D2 & $12: 19: 10-12: 48: 16$ & $3100-3750$ & -5 to -1 \\
\hline
\end{tabular}

including temperature measured by Goodrich Rosemount probes (models; 102E4AL and 102AU1AG for non-deiced, and deiced temperatures, respectively, similar to those used on the FAAM aircraft) and altitude derived from the aircraft avionics (Litef AHRS) system.

\subsection{Data analysis}

During each science flight, measurements of aerosol and cloud microphysical properties were made. The techniques used to interpret these data are described below. The flights and the conditions during some of the measurement periods can be found in Table 1 .

\section{Cloud microphysics measurements}

In this paper, $1 \mathrm{~Hz}$ data from all cloud and aerosol instruments have been further averaged over $10 \mathrm{~s}$ periods for presentation. Measurements from the 2D-S probe have been presented in preference to other 2-D probe data due to this probe's significantly faster response time (by $>$ a factor of 10 ) and greater resolution. When comparing CIP-15 and 2D$\mathrm{S}$ size distributions we found good agreement over their respective size ranges. During the spring cases it was possible to combine 2D-S data with measurements from the CIP-100 to extend the cloud particle size range. Analysis of imagery from these optical array probes (OAPs) was used to calculate number concentrations and discriminate particle phase. Identification of irregular particles, assumed to be ice, was achieved through examination of each particle's circularity (Crosier et al., 2011). Ice water contents (IWCs) were determined using the Brown and Francis (1995) mass dimensional relationship. This mass dimensional relationship is widely used in the literature for mixed-phase clouds (e.g. Crosier et al., 2011). Baker and Lawson (2006) found discrepancies between their treatments of data using habit recognition and the Brown and Francis scheme. In our case studies where the IWC is high, most of the mass is dominated by small ice crystals, for which good agreement is found between Brown and Francis and Baker and Lawson.

All cloud microphysics probes were fitted with "antishatter" tips (Korolev et al., 2011, 2013) to mitigate particle shattering on the probe . However, even with these modifications shattering artifacts may still be present, particularly under some cloud conditions, and these need to be corrected for (Field et al., 2006). To minimise such artifacts, inter-arrival time (IAT) histograms were analysed in an attempt to identify and remove these additional particles, i.e. by removing particles with very short IATs that are indicative of shattered ice crystals. Crosier et al. (2013) reported that careful analysis of IAT histograms for different cloud microphysical conditions is needed to determine the most appropriate IAT threshold for best case elimination of such artifacts. For example, in regions of naturally high ice crystal number concentrations, such as in the $\mathrm{H}-\mathrm{M}$ secondary ice production temperature zone, the minimum IAT threshold may need to be reduced more than is usual so as not to exclude too many naturally generated ice crystals with short IATs. In this study, we found a minimum IAT threshold of $1 \times 10^{-5}$ and $2 \times 10^{-5} \mathrm{~s}$ for the 2D-S and CIP-15 instruments, respectively, to be appropriate IAT values for the majority of cloud region data presented.

It was found that the CIP probes and 2D-S ice crystal number concentrations differed by less than $20 \%$ over their common size range. In this paper we present the data from the 2D-S due to its larger size range, higher resolution and faster response time. 
Table 2. Measurements of aerosol concentrations $>0.5 \mu \mathrm{m}$ from the CAS and PCASP probes, together with predicted primary IN number using the DeMott et al. (2010) (D10) scheme (with either CAS or PCASP aerosol concentration data as input). Observed minimum median cloud temperatures were input to D10, and IN predictions were compared with observed maximum median ice concentrations.

\begin{tabular}{lrrrrrrr}
\hline Flight & $\begin{array}{r}\text { Max median } \\
\text { ice }\left(\mathrm{L}^{-1}\right)\end{array}$ & $\begin{array}{r}\text { Min median } \\
\text { temp }(\mathrm{C})\end{array}$ & $\begin{array}{r}\text { Max } \\
\text { RH }(\%)\end{array}$ & $\begin{array}{r}\text { CAS aerosol } \\
\text { conc }\left(\mathrm{cm}^{-3}\right)\end{array}$ & $\begin{array}{r}\text { PCASP aerosol } \\
\text { conc }\left(\mathrm{cm}^{-3}\right)\end{array}$ & $\begin{array}{r}\text { Predicted CAS } \\
\text { IN value }\left(\mathrm{L}^{-1}\right)\end{array}$ & $\begin{array}{r}\text { Predicted PCASP } \\
\text { IN value }\left(\mathrm{L}^{-1}\right)\end{array}$ \\
\hline Case 1a & 0.61 & -18.7 & 90.3 & $0.99 \pm 0.25$ & $3.13 \pm 1.74$ & $1.02 \pm 1.14 / 0.88$ & $1.80 \pm 2.25 / 1.20$ \\
Case 1b & 0.61 & -18.7 & 22.16 & $0.14 \pm 0.1$ & $4.94 \pm 2.22$ & $0.38 \pm 0.50 / 0.21$ & $2.26 \pm 2.72 / 1.68$ \\
Case 1c & 0.61 & -18.7 & 85.43 & $1.48 \pm 0.37$ & $4.04 \pm 2.25$ & $1.24 \pm 1.34 / 1.08$ & $2.05 \pm 2.55 / 1.37$ \\
\hline Case 2a & 0.47 & -16.2 & 69.68 & $1.50 \pm 0.30$ & $3.23 \pm 1.68$ & $0.76 \pm 0.82 / 0.69$ & $1.05 \pm 1.26 / 0.77$ \\
Case 2b & 0.47 & -16.2 & 92.60 & $2.40 \pm 0.32$ & $4.96 \pm 2.28$ & $0.93 \pm 0.98 / 0.87$ & $1.27 \pm 1.49 / 097$ \\
Case 2c & 0.47 & -16.2 & 93.86 & $2.07 \pm 6.57$ & $3.07 \pm 1.86$ & $0.87 \pm 1.61 /$ & $1.03 \pm 1.26 / 0.69$ \\
\hline Case 3a & 3.35 & -10 & 89.37 & $0.06 \pm 0.07$ & - & $0.06 \pm 0.07 /$ & - \\
Case 3b & 3.35 & -10 & 59.66 & $0.15 \pm 0.11$ & - & $0.08 \pm 0.09 / 0.05$ & - \\
Case 3c & 3.35 & -10 & 89.79 & $0.33 \pm 0.76$ & - & $0.10 \pm 0.13 /$ & - \\
Case 3d & 3.35 & -10 & 89.70 & $0.48 \pm 0.21$ & - & $0.11 \pm 0.12 / 0.09$ & - \\
\hline Case 4a & 2.50 & -4.3 & 79.70 & $3.73 \pm 1.03$ & - & $0.009 \pm 0.009 / 0.009$ & - \\
Case 4b & 2.50 & -4.3 & 73.46 & $4.03 \pm 0.58$ & - & $0.009 \pm 0.009 / 0.009$ & - \\
Case 4c & 2.50 & -4.3 & 31.57 & $0.24 \pm 0.14$ & - & $0.007 \pm 0.007 / 0.006$ & - \\
\hline
\end{tabular}

\subsection{Aerosol measurements}

We did not directly measure IN concentrations during each flight, however information in each case study, about aerosol concentration and size was used to calculate the predicted primary IN concentrations from the DeMott et al. (2010, hereafter D10) parameterisation of primary ice nuclei numbers, which is dependent on the number concentration of aerosol particles with diameters $>0.5 \mu \mathrm{m}$. Combined measurements of the aerosol concentration using the PCASP and CAS for spring, and CAS for summer, were used from cloudfree regions selected by applying maximum relative humidity (RH) thresholds. This was done to reduce the contribution of any haze aerosol particles smaller than $0.5 \mu \mathrm{m}$ in size growing into the size range at higher humidities and being incorrectly included. The CAS instrument has a lower size threshold of $0.51 \mu \mathrm{m}$. D10 notes that the maximum possible aerosol size that could be measured and included in their D10 parameterisation was $1.6 \mu \mathrm{m}$. However, due to the size bins utilised by the CAS instrument this upper threshold had to be relaxed to $2 \mu \mathrm{m}$, although the extra contribution to the aerosol concentrations used in the calculations is likely to be small. Measurements from the higher-resolution PCASP were selected from the size range of $0.5-1.6 \mu \mathrm{m}$, in keeping with the D10 scheme. The D10-predicted IN concentrations were then compared directly as a function of temperature with the observed ice crystal concentrations. The minimumobserved median temperature was input to D10 and predicted IN numbers compared with the maximum-observed median ice crystal number concentrations (Fig. 11) for the clouds during each of the four cases. The results are shown in Table 2 .
The results of this comparison from all four cases can be compared with previous observations of Arctic clouds and with recent aircraft measurements of clouds over the Antarctic Peninsula in the summer (Grosvenor et al., 2012).

\section{Spring case 1 - Friday 22 March 2013 (FAAM flight B761)}

The FAAM aircraft flew from Kiruna, Sweden $\left(67.85^{\circ} \mathrm{N}\right.$, $20.21^{\circ} \mathrm{E}$ ), to Svalbard, Norway, landing at Longyearbyen, $\left(78.22^{\circ} \mathrm{N}, 15.65^{\circ} \mathrm{E}\right)$ to refuel. After takeoff at $\sim 11: 45 \mathrm{UTC}$ $\mathrm{a} \sim 2 \mathrm{~h}$ science flight was undertaken to the south-east of Svalbard (Fig. 1) before returning to Kiruna. The objective was to investigate stratocumulus clouds over a north-south line in this area. The flight focused on a series of profiled descents and ascents to enable measurements to be made of the cloud layer from below the cloud base to above the cloud top and into the inversion layer above. During the flight there were three significant penetrations through the inversion at cloud top and in each case there was a marked temperature increase of $\sim 5^{\circ} \mathrm{C}$. Microphysical time series data for this case are presented, with the relevant runs highlighted in Fig. 2. A description of one cloud profile is given here, with further profiles described in the Supplement.

Boundary layer aerosol number concentrations (from the PCASP) were found to be relatively low at $\sim 50-100 \mathrm{~cm}^{-3}$. A blocking high-pressure system east of Greenland was present, with a trough over eastern Scandinavia. The area of operation was situated on the north-eastern side of the anticyclone with widespread low cloud observed south and east of Svalbard (Fig. 1), with winds from the north advecting from over the sea ice towards open sea. Earlier drop- 

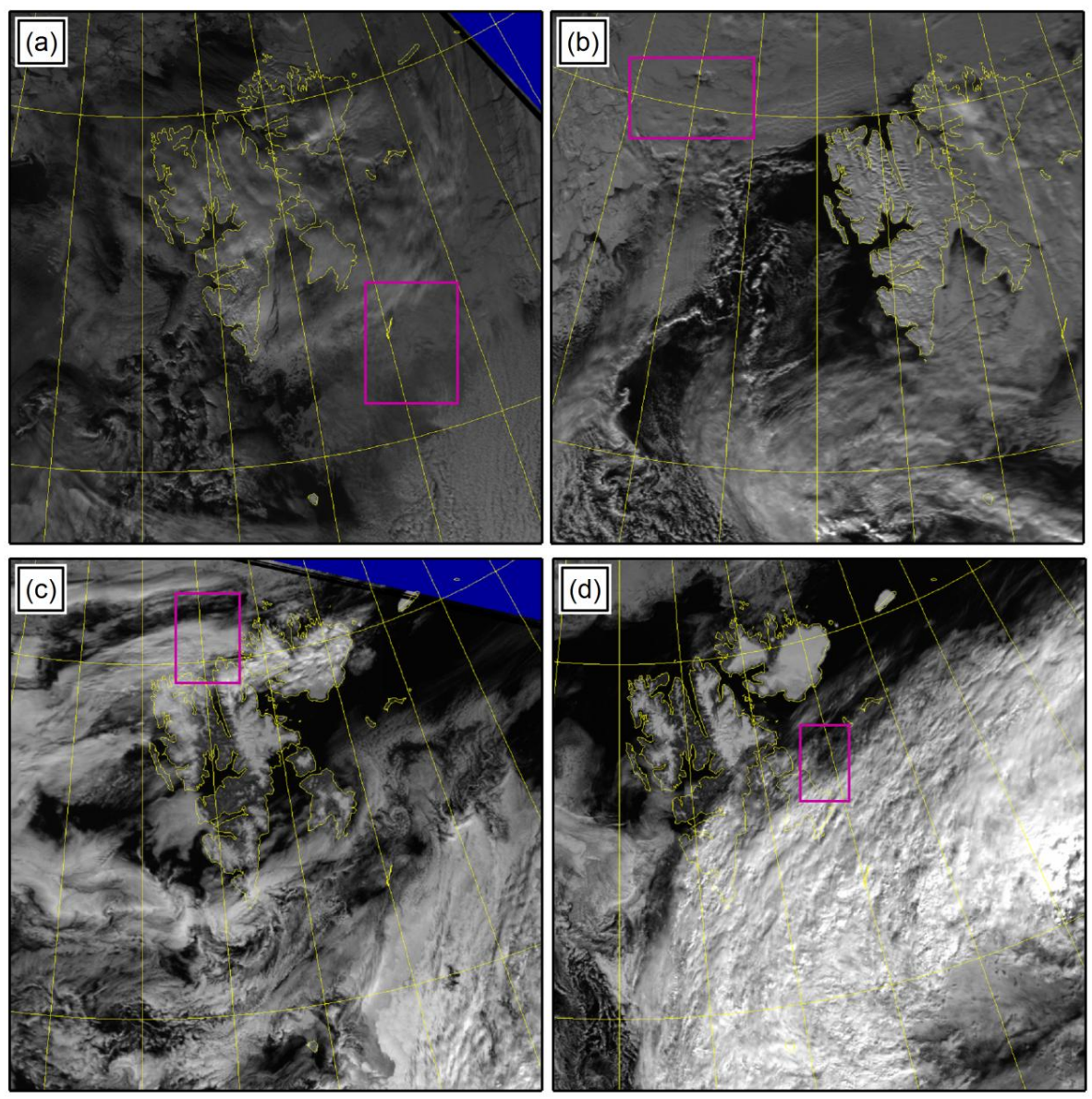

Figure 1. AVHRR visible satellite imagery for spring case 1 (a), spring case 2 (b), summer case 1 (c) and summer case 2 (d). The science flight area is highlighted by purple boxes in each figure.

sonde measurements (on the transit into Longyearbyen prior to refuelling) showed surface winds of $\sim 3 \mathrm{~m} \mathrm{~s}^{-1}$ increasing to $15 \mathrm{~m} \mathrm{~s}^{-1}$ at $500 \mathrm{mb}$. The cloud layers during this flight were found to contain generally uniform liquid water content profiles, which were found to be approximately adiabatic. The clouds were situated over the temperature range of $-15^{\circ} \mathrm{C}<T<-20^{\circ} \mathrm{C}$. Generally low concentrations of ice, often in isolated pockets, were observed in these clouds.

\section{Profiled descent A1}

During profile A1 the aircraft (now travelling north) descended from the inversion layer. Cloud top was encountered at $1650 \mathrm{~m}\left(T=-18.6^{\circ} \mathrm{C}\right)$. The highest values of $N_{\text {ice }}$ were observed in the cloud top region, at $\sim 4 \mathrm{~L}^{-1}$. Particles here consisted of small irregular ice particles (mean size $\sim 360 \mu \mathrm{m}$ ) that showed evidence of riming, together with small droplets. LWC at cloud top increased to $0.3 \mathrm{~g} \mathrm{~m}^{3}$ with $N_{\text {drop }} \sim 55 \mathrm{~cm}^{-3}$ (mean diameter $\sim 17 \mu \mathrm{m}$ ). As the aircraft descended ( $\sim 250 \mathrm{~m}$ below cloud top) $N_{\text {ice }}$ decreased to $\sim 1 \mathrm{~L}^{-1}$, while mean ice particle size increased to $\sim 395 \mu \mathrm{m}$. $N_{\text {drop }}$ increased to $\sim 70 \mathrm{~cm}^{-3}$, while mean size decreased slightly $(\sim 16 \mu \mathrm{m})$, while LWCs generally decreased somewhat to $\sim 0.2 \mathrm{~g} \mathrm{~m}^{-3}$. In spring cases this pattern of steadily reducing LWC with an increase in droplet number towards cloud base was frequently observed (Fig. 10). As the aircraft descended to an altitude of $\sim 1150 \mathrm{~m}, N_{\text {ice }}$ increased by approximately a factor of 2 (to $\sim 2 \mathrm{~L}^{-1}$ ). At around 13:15 UTC a number of rapid transitions from liquid to predominantly glaciated conditions were observed in the mid cloud region at $730 \mathrm{~m}$ and $T=-12^{\circ} \mathrm{C} .2 \mathrm{D}-\mathrm{S}$ imagery (Fig. 3c) highlights these changes taking place as small droplets are quickly replaced by small irregular ice crystals and eventually larger snow particles (mean diameter $\sim 610 \mu \mathrm{m}$ ) that consisted of heavily rimed ice crystals and aggregates, some of which can be identified as exhibiting a dendritic habit. Three further swift phase transitions were observed as the aircraft approached cloud base. LWC in the liquid-dominated regions was between $\sim 0.15$ and $0.25 \mathrm{~g} \mathrm{~m}^{-3}$ while $N_{\text {drop }}$ peaked at $\sim 130 \mathrm{~cm}^{-3}$. During the ice-phase sections of the transition cycle, mean particle sizes were $\sim 615 \mu \mathrm{m}$ and $N_{\text {ice }}$ was a few per litre. The contribution of these glaciated cloud regions to the IWC was considerable, with values around $0.1 \mathrm{~g} \mathrm{~m}^{-3}$ 


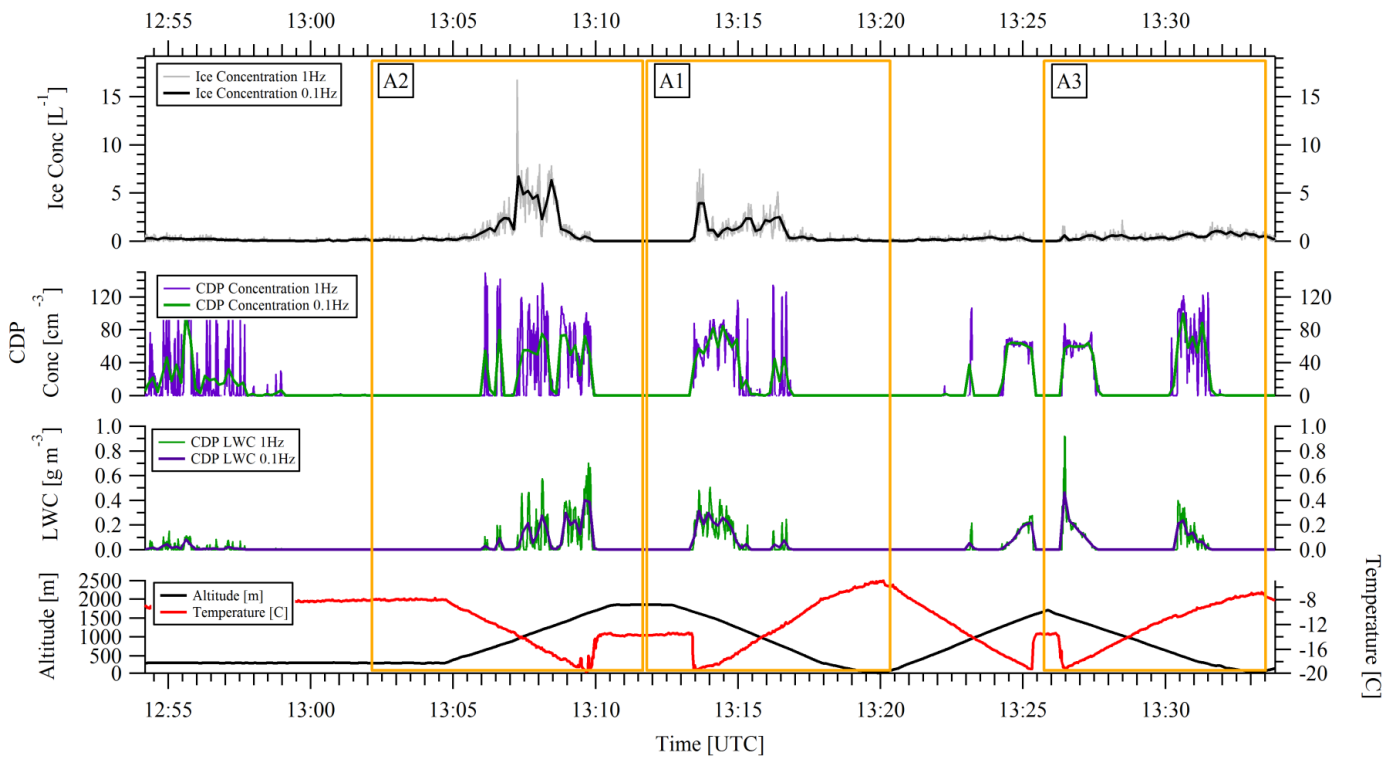

Figure 2. Microphysics time series for spring case 1 . Data includes temperature $\left({ }^{\circ} \mathrm{C}\right)$ and altitude (m) (lower panel) together with 1 and $10 \mathrm{~s}$ data sets for CDP liquid water content $\left(\mathrm{g} \mathrm{m}^{-3}\right)$ (panel 2 from bottom), CDP cloud particle number concentration $\left(\mathrm{cm}^{-3}\right)($ panel 3$)$ and ice water content $\left(\mathrm{g} \mathrm{m}^{-3}\right)$ and ice number concentrations $\left(\mathrm{L}^{-1}\right)$ (top panel). Profiles A2 and A3 are described in the Supplement.

recorded. These transitions ended as the aircraft descended below cloud base $\left(T=-12{ }^{\circ} \mathrm{C}\right)$ at $700 \mathrm{~m}$ a.s.l., and precipitating snow was observed (mean size $\sim 710 \mu \mathrm{m}$ ). Measurements of the ice phase during spring cases often showed increasing ice crystal size towards cloud base, with the largest ice particles measured in precipitation from the cloud layers above.

\section{Spring case 2 - Wednesday 3 April 2013 (FAAM flight B768)}

The FAAM aircraft departed Longyearbyen at around 11:00 UTC and conducted measurements to the NW of Svalbard to investigate low-level clouds over the sea ice (moving from NW to SE in the target area - Fig. 1). A low pressure $(1004 \mathrm{mb})$ region was centred south of Svalbard with an associated band of cloud and precipitation. To the NW of Svalbard, within the measurement area, surface winds were ENE and $<10 \mathrm{~m} \mathrm{~s}^{-1}$. Measurements revealed an air mass containing significantly more aerosol than in Spring case 1, with PCASP concentrations typically $\sim 300-400 \mathrm{~cm}^{-3}$ in the boundary layer. During the flight the aircraft made two distinct sawtooth profiles through the cloud layer and into the inversion above cloud top where temperatures in each instance increased by $\sim 2{ }^{\circ} \mathrm{C}$. Figure 4 shows time series of the microphysical measurements made during this science flight. Further profile descriptions can be found in the Supplement. Despite the contrast in aerosol loadings when compared with the first spring case, where aerosol concentrations were much lower, the cloud layers were similar with generally uniform structure and low concentrations of primary ice. Despite the cloud layers being situated in slightly higher temperatures $\left(-12{ }^{\circ} \mathrm{C}<T<-16^{\circ} \mathrm{C}\right)$, the concentrations of ice were similar to spring case 1 .

\section{Profiled descent B1}

Flying NW, the aircraft performed a profiled descent from the inversion layer $\left(T=-16.5^{\circ} \mathrm{C}\right)$ into cloud top, $\sim 1550$ ma.s.l., where the measured temperature was $-17^{\circ} \mathrm{C}$. LWCs rose to $\sim 0.9 \mathrm{~g} \mathrm{~m}^{-3}$ and $N_{\text {drop }}$ (mean diameter $\sim 15 \mu \mathrm{m}$ ) peaked at $\sim 320 \mathrm{~cm}^{-3}$. The highest values of $N_{\text {ice }}$ never exceeded $0.5 \mathrm{~L}^{-1}$ in this cloud top region and imagery from the $2 \mathrm{D}-\mathrm{S}$ probe revealed many small droplets with isolated small (mean size $\sim 223 \mu \mathrm{m}$ ) irregular ice crystals (Fig. 5a). After descending through this brief cloud top region $N_{\text {ice }}$ increased to $\sim 0.5 \mathrm{~L}^{-1}$. As the aircraft descended over the next $500 \mathrm{~m}$ mean droplet concentrations gradually increased from 300 to $370 \mathrm{~cm}^{-3}$ with mean diameters decreasing slightly to $12.5 \mu \mathrm{m}$. LWCs fell from 0.7 to $0.2 \mathrm{~g} \mathrm{~m}^{-3}$ over the same period, a pattern consistent with spring case $1 . N_{\text {ice }}$ values remained fairly constant and IWCs were $<0.02 \mathrm{~g} \mathrm{~m}^{-3}$. 2D-S imagery showed ice crystals (mean diameter $295 \mu \mathrm{m}$ ) to be mainly dendritic in nature. During the last $160 \mathrm{~m}$ depth of the cloud, before cloud base, $N_{\text {ice }}$ remained similar to the mid cloud region. However, concentrations of liquid droplets measured by the CDP showed greater variability. Peaks in number concentrations reached up to $430 \mathrm{~cm}^{-3}$, with rapid changes down to $110 \mathrm{~cm}^{-3}$.

The aircraft passed cloud base at $700 \mathrm{~m}$ a.s.l. encountering low concentrations $\left(<0.5 \mathrm{~L}^{-1}\right)$ of precipitating snow. Inter- 

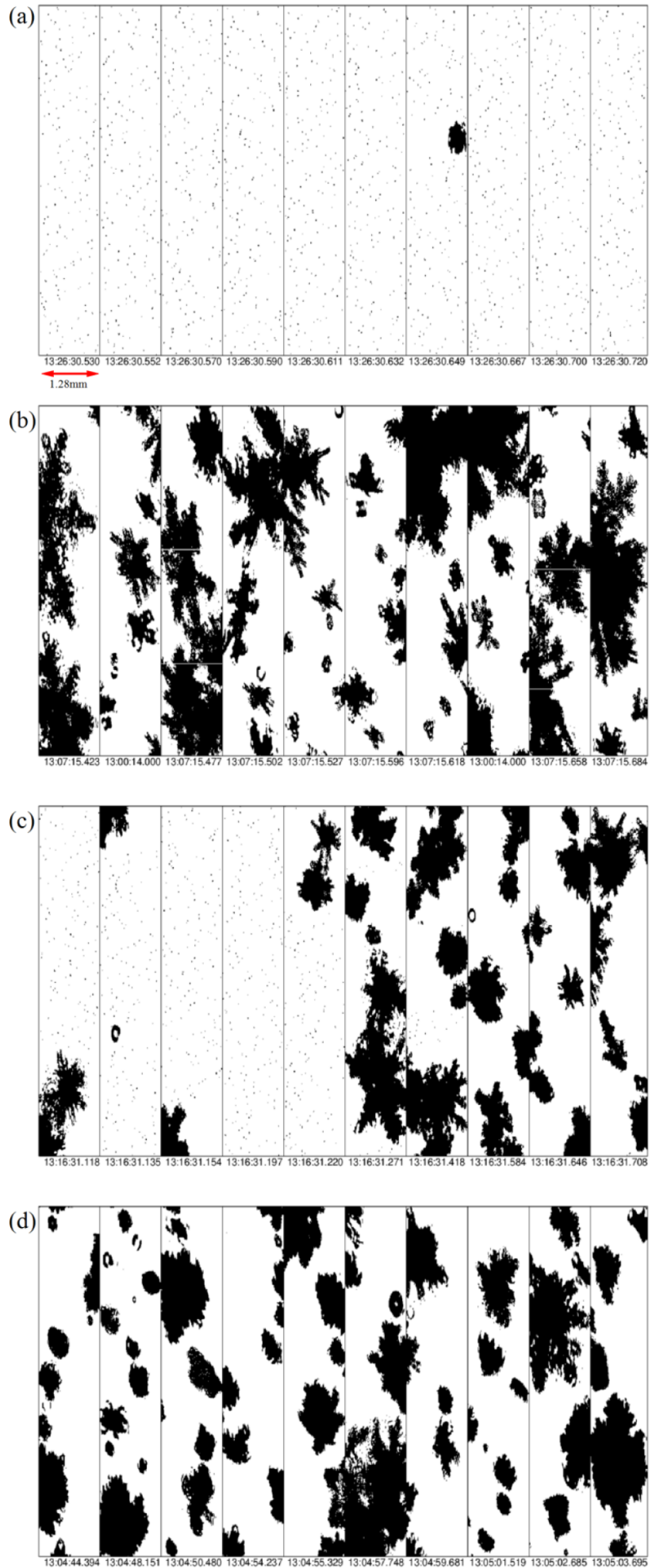

Figure 3. Images from the 2D-S cloud probe during spring case 1 from (a) a cloud top region during A1, (b) $500 \mathrm{~m}$ below cloud top during A2, (c) region of swift transitions between ice and liquid, and (d) a precipitation region below cloud base. estingly, as the aircraft continued its descent (to $50 \mathrm{~m}$ a.s.1.) a significant increase in $N_{\text {ice }}$ was observed $\left(T=-9^{\circ} \mathrm{C}\right)$, with $10 \mathrm{~s}$ mean values of $2 \mathrm{~L}^{-1}$. Images from the $2 \mathrm{D}-\mathrm{S}$ revealed (Fig. 5d) snow precipitation co-existing with small columnar ice crystals. CDP LWC was very low, $<0.01 \mathrm{~g} \mathrm{~m}^{-3}$; however, examination of the 2D-S imagery showed the presence of spherical drizzle droplets larger than the maximum detectable size of the CDP. Size distribution data from the 2D$\mathrm{S}$ in this region revealed an additional mode dominated by these smaller columnar ice crystals, typically $80 \mu \mathrm{m}$ in size. As the aircraft ascended again, these higher concentrations of ice crystals diminished.

\section{Summer case 1 - Tuesday 18 July 2013 (flight number M191)}

The BAS Twin Otter aircraft departed Longyearbyen airport at $\sim$ 07:00 UTC to conduct a $\sim 2 \mathrm{~h}$ science flight to the north of Svalbard (Fig. 1). Examination of surface pressure charts showed a slack low pressure around Svalbard, with an occluded front to the east. Extensive low clouds were present in the area with light winds $<5 \mathrm{~m} \mathrm{~s}^{-1}$ from the north. The objectives of the flight were to measure aerosol concentrations and composition in the vicinity of clouds, together with the microphysical properties of the clouds by undertaking a combination of profiles and straight and level runs through stratocumulus cloud layers to capture the microphysical structure. Time series of data collected during this flight are presented in Fig. 6. Profile $\mathrm{C} 2$ is described below, with details of the measurements made during $\mathrm{C} 1$ found in the Supplement. Cloud layers during this case were found to be situated in the $\mathrm{H}-\mathrm{M}$ temperature zone with greater variability in microphysical structure when compared with the spring cases. At cloud top, ice concentrations were found to be similar to the spring cases. However, at times, in the body of the cloud secondary ice production caused significant areas of glaciated cloud, which appeared to lead to greater variability in the liquid water profile of the clouds when compared to the colder layers observed in the spring.

\section{Profile C2}

The aircraft performed a sawtooth profile, descending from cloud top at $\sim 3300 \mathrm{~m}$ down to a minimum altitude of $\sim 2300 \mathrm{~m}$ followed by a profiled ascent to complete the sawtooth. During the descent into cloud top $\left(T=-9^{\circ} \mathrm{C}\right)$, LWCs rose sharply to peak values of $0.3 \mathrm{~g} \mathrm{~m}^{-3}$ and $N_{\text {drop }}$ (mean diameter $19 \mu \mathrm{m}$ ) increased to $155 \mathrm{~cm}^{-3} . N_{\text {ice }}$ in the cloud top regions peaked at $1 \mathrm{~L}^{-1}$. With decreasing altitude, $\mathrm{LWC}$ declined gradually to values close to $0.01 \mathrm{~g} \mathrm{~m}^{-3}$. As the temperature increased to above $-8^{\circ} \mathrm{C}$, ice crystal number concentrations (mean diameter $210 \mu \mathrm{m}$ ) increased to $5 \mathrm{~L}^{-1}$, with peaks at $\sim 12 \mathrm{~L}^{-1}$. 2D-S imagery revealed the presence of small columnar ice crystals together with small liquid 


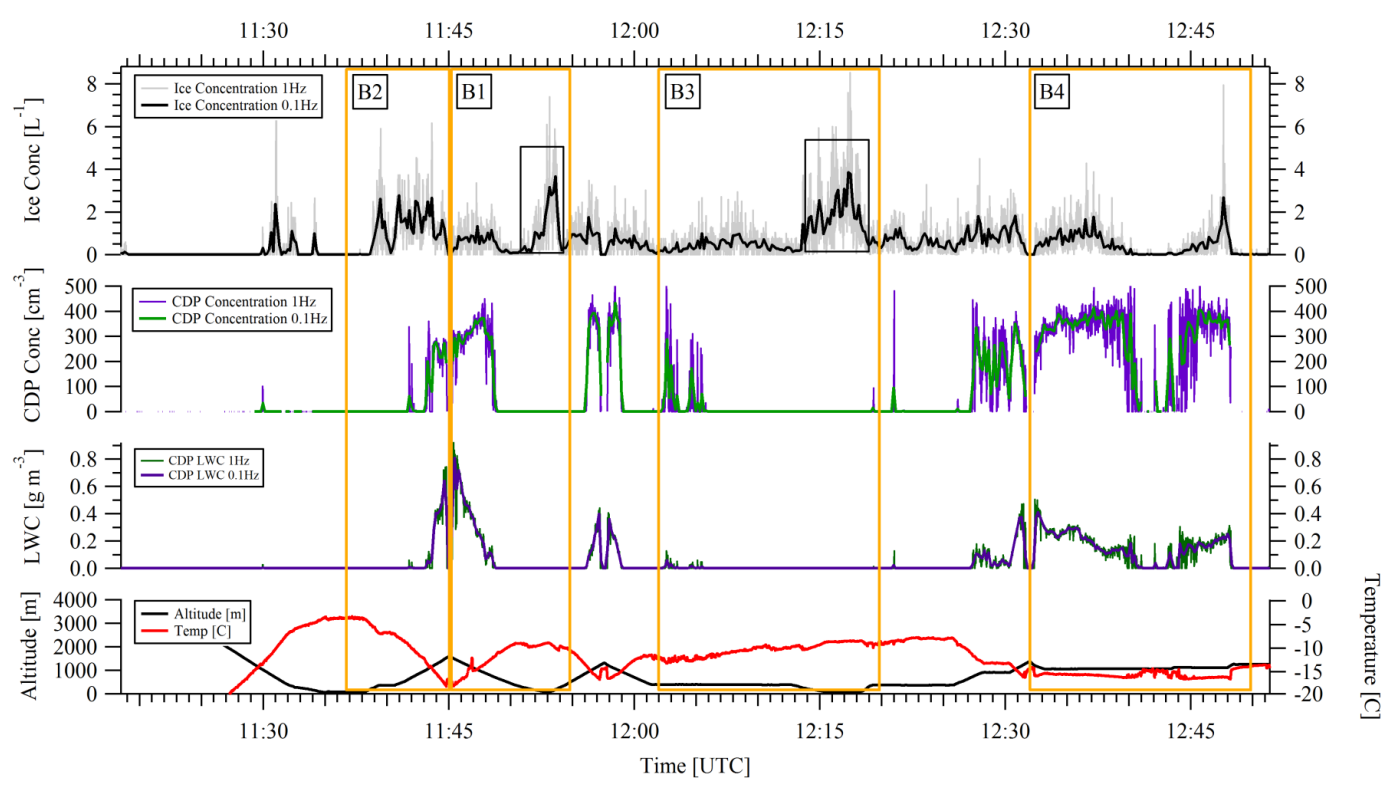

Figure 4. Microphysics time series data for spring case 2. Data includes temperature $\left({ }^{\circ} \mathrm{C}\right)$ and altitude (m) (lower panel) 1 and $10 \mathrm{~s}$ data sets for CDP liquid water content $\left(\mathrm{g} \mathrm{m}^{-3}\right)$ and CDP concentration $\left(\mathrm{cm}^{-3}\right)$ (middle panels), and ice water content $\left(\mathrm{g} \mathrm{m}^{-3}\right)$ and ice number concentrations $\left(\mathrm{L}^{-1}\right)$ (top panel). Profiles B2, B3 and B4 are described in the Supplement.

droplets (CDP mean diameter $8.5 \mu \mathrm{m}$ ) and some irregular ice particles. Low concentrations of ice at cloud top was consistent in both summer cases, with periods of enhanced concentrations due to rime splintering lower in the clouds.

At $2880 \mathrm{~m}\left(T=-6.5^{\circ} \mathrm{C}\right)$ the cloud dissipated until the next cloud layer was encountered $200 \mathrm{~m}$ below $\left(T=-5^{\circ} \mathrm{C}\right)$. In this region CDP LWC and $N_{\text {drop }}$ were more variable than in the cloud layer above. Generally, LWCs were $<0.1 \mathrm{~g} \mathrm{~m}^{-3}$ with peaks in $N_{\text {drop }}$ up to $\sim 155 \mathrm{~cm}^{-3}$ and transitions between liquid cloud and predominantly glaciated cloud were observed. During glaciated periods 2D-S imagery showed many columnar ice crystals, typical of the growth regime at this temperature $\left(\sim-5^{\circ} \mathrm{C}\right)$ and consistent with the enhancement of $N_{\text {ice }}$ through the $\mathrm{H}-\mathrm{M}$ process. Greater variation in microphysical structure, with broken cloud layers and transitions between liquid and glaciated phases, was evident in the summer cases, which was in contrast to the uniform spring cloud layers.

\section{Summer case 2 - Wednesday 19 July 2013 (M192)}

The BAS aircraft departed Longyearbyen at $\sim$ 09:00 UTC intending to investigate cloud microphysics and aerosol properties to the north of Svalbard (Fig. 1). On arrival at the observation area the forecasted cloud was not present so the flight was diverted to the south-east of Svalbard to meet an approaching cloud system. Surface pressure charts showed a low pressure system over Scandinavia (central pressure $1002 \mathrm{mb}$ ), with a warm front south-east of Svalbard that was moving to the north-west. Surface winds in this area were $\sim 13 \mathrm{~m} \mathrm{~s}^{-1}$ from the north-east. In situ cloud microphysics measurements were made for approximately $1.5 \mathrm{~h}$ in total. To meet the objectives of the flight, straight and level runs and sawtooth profiles were performed through the cloud layers. Microphysics time series data from the flight are shown in Fig. 8. Profile D2 is described below, with the additional profile D1 discussed in the Supplement. This second summer case was again found to have different microphysical characteristics when compared with spring cases. Higher ice number concentrations and the domination of the ice phase by secondary ice formation caused much greater variability in the structure of the clouds observed.

\section{Profile D2}

During period D2, the aircraft performed a number of straight and level runs combined with sawtooth profiles to capture the microphysical structure of the cloud layers present. At $3100 \mathrm{~m}$ the aircraft flew a straight and level run below cloud base and encountered a region of snow precipitation at temperatures between -2 and $-3{ }^{\circ} \mathrm{C}$. $N_{\text {ice }}$ peaked at $5 \mathrm{~L}^{-1}$ giving peaks in calculated IWCs of $\sim 0.1 \mathrm{~g} \mathrm{~m}^{-3}$. Probe imagery showed ice crystals (mean diameter $410 \mu \mathrm{m}$ ) dominated by irregular particles, with some evidence of plate-like and dendritic structures. Observation of snow precipitation below some cloud layers is a common observation in both spring and summer cases.

During a profiled ascent up to $3400 \mathrm{~m}$ (to begin an extended SLR - straight and level run) the aircraft penetrated cloud base at $3300 \mathrm{~m}\left(T=-4{ }^{\circ} \mathrm{C}\right)$. LWCs rose to $\sim 0.1 \mathrm{~g} \mathrm{~m}^{-3}$ with $N_{\text {drop }}$ generally observed to be between 10 

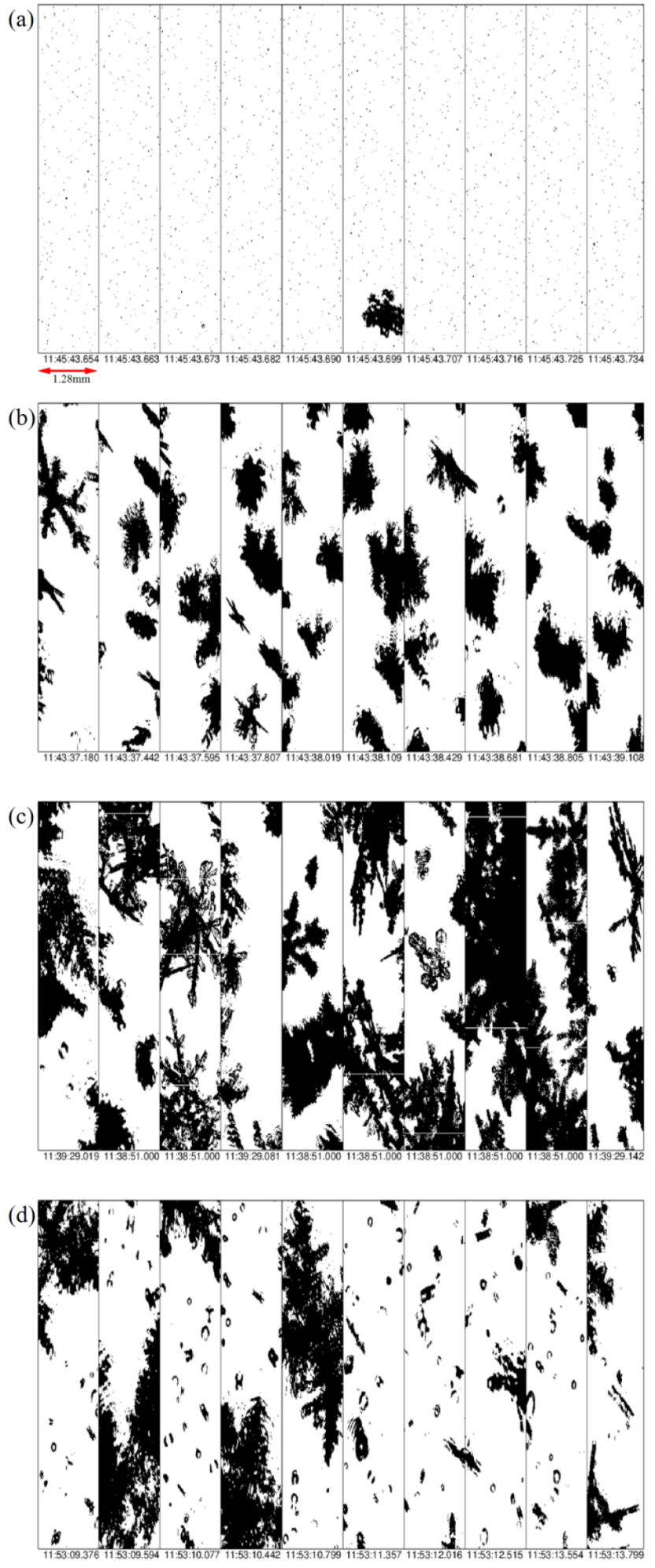

Figure 5. Images from the 2D-S cloud probe from spring case 2 for (a) cloud top during B1, (b) profiled ascent during B2, (c) dendritic ice in the cloud base region during B2, and (d) columnar ice above the sea surface during B2. and $50 \mathrm{~cm}^{-3}$ (mean diameter $12 \mu \mathrm{m}$ ). $N_{\text {ice }}$ in this region was between 0 and $1 \mathrm{~L}^{-1}$ and crystals consisted of irregular ice particles, columnar ice and small liquid droplets. The mean diameter of the ice particles in this region was $470 \mu \mathrm{m}$. Continuing at $3400 \mathrm{~m}$ altitude, the aircraft encountered a break in the cloud layer that lasted for around $1 \mathrm{~min}(\sim 6 \mathrm{~km})$, before a subsequent cloud layer was observed that had similar LWCs to the previous cloud layer $\left(\sim 0.1 \mathrm{~g} \mathrm{~m}^{-3}\right)$ but with generally lower droplet concentrations (of mean diameter $17.5 \mu \mathrm{m}$ ) with mean $N_{\text {drop }}$ values of $15-30 \mathrm{~cm}^{-3} . N_{\text {ice }}$ values in this region were lower than before $\left(<0.5 \mathrm{~L}^{-1}\right)$. The sampling of this cloudy region was brief before another gap in cloud was observed that lasted $\sim 2 \mathrm{~min}$. The end of this second clear region was defined by a sudden transition to columnar ice and small irregular particles (mean diameter $410 \mu \mathrm{m}$ ) in concentrations up to a peak of $4 \mathrm{~L}^{-1}$. This region was mostly glaciated with $\mathrm{LWC}<0.01 \mathrm{~g} \mathrm{~m}^{-3}$. During this SLR there were very swift transitions observed between predominantly glaciated regions containing ice crystals of a columnar nature and then mainly liquid regions consisting of low concentrations $\left(<30 \mathrm{~cm}^{-3}\right)$ of small liquid droplets (mean diameter $14 \mu \mathrm{m})$ and LWCs $\left(\sim 0.01 \mathrm{~g} \mathrm{~m}^{-3}\right)$ (Fig. 9c-d). This predominantly glaciated period ended when the aircraft performed a profiled ascent and $N_{\text {ice }}$ decreased to $<0.5 \mathrm{~L}^{-1}$ while LWCs increased to a peak of $0.3 \mathrm{~g} \mathrm{~m}^{-3}$ and $N_{\text {drop }}$ rose to a maximum of $\sim 120 \mathrm{~cm}^{-3}$ (mean diameter $14 \mu \mathrm{m}$ ). The aircraft penetrated cloud top at $3700 \mathrm{~m}\left(T=-4.5^{\circ} \mathrm{C}\right)$. During subsequent passes through the $\mathrm{H}-\mathrm{M}$ zone during period $\mathrm{D} 2$, further peaks in ice concentrations up to $20 \mathrm{~L}^{-1}$, attributed to rime splintering, were observed.

\section{Primary IN parameterisation comparison}

Ice number concentrations as a function of altitude for science flight periods have been presented and here these observations are compared to calculations of the primary IN concentrations predicted using the D10 scheme, using aerosol concentrations (diameter $>0.5 \mu \mathrm{m}$ ) that were measured on each flight as input. DeMott et al. (2010) analysed data sets of IN concentrations over a 14-year period from a number of different locations and found that these could be related to temperature and the number of aerosol $>0.5 \mu \mathrm{m}$. The parameterisation provided an improved fit to the data sets and predicted $62 \%$ of the observations to within a factor of 2 . Table 2 shows mean aerosol concentrations for measurement periods during each case, the input temperature to D10, the maximum median ice concentration used for comparison and the predicted IN concentration based on both the PCASP and CAS aerosol measurements (where available). During the spring measurement campaign it was possible to compare the CAS and PCASP probe data sets. Despite some variation in concentrations reported between the two instruments, D10-predicted IN values were found to be fairly insensitive to these differences. Grosvenor et al. (2012) highlighted that 


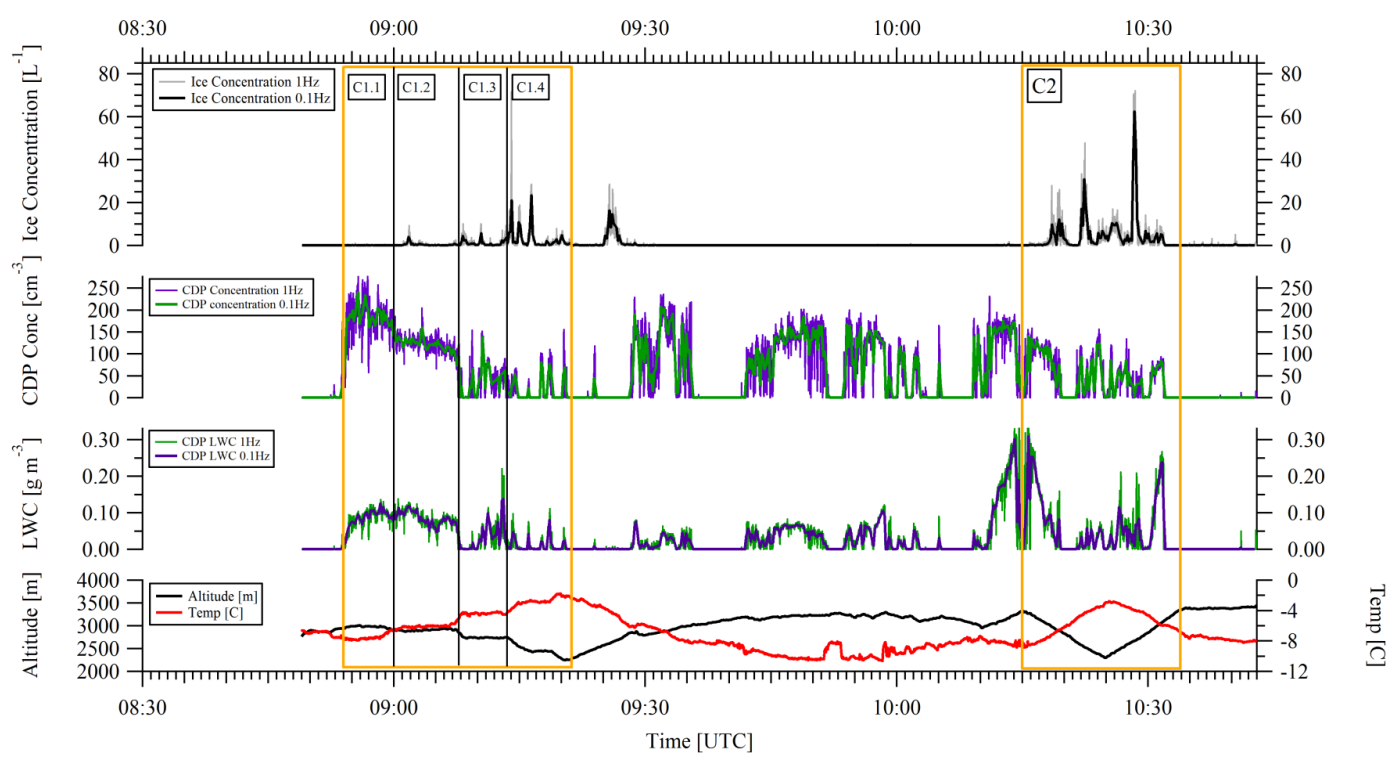

Figure 6. Microphysics time series data for summer case 1 . Data includes temperature $\left({ }^{\circ} \mathrm{C}\right)$ and altitude $(\mathrm{m})$ (lower panel) together with 1 and $10 \mathrm{~s}$ data sets for CDP liquid water content $\left(\mathrm{g} \mathrm{m}^{-3}\right)$ (second panel up), CDP concentrations $\left(\mathrm{cm}^{-3}\right)$, ice water content $\left(\mathrm{g} \mathrm{m}^{-3}\right)$ and ice number concentrations $\left(\mathrm{L}^{-1}\right)$ (top panels). Flight segments C1.1, C1.2, C1.3 and C1.4 are described in the Supplement.

changes of about a factor of 4 produced a very limited change in the IN concentrations predicted by the scheme.

In spring case 1 the maximum median ice value was $0.61 \mathrm{~L}^{-1}$ so predicted IN values were generally higher (between a factor of 2 and 4) than this median ice concentration observation. However, peaks in ice concentrations of up to $\sim 10 \mathrm{~L}^{-1}$ were also observed (Fig. 2), so on these occasions D10 significantly underpredicts observed ice number concentrations when compared to these peak values. During spring case 2 , maximum median ice concentration values were similar to spring case 1 . Secondary ice production was observed close to the sea surface in this case so these higher median concentrations have been disregarded for the purposes of the D10 primary IN comparison. Aerosol measurements from the CAS were lower than from the PCASP but predicted IN values were in good agreement (less than a factor of 2) with the observed maximum median concentration. The peak concentrations observed during the flight were $\sim 5 \mathrm{~L}^{-1}$ (Fig. 4 ) and as in the first spring case D10 underpredicted these peak concentrations by about a factor of 10.

During summer case 1 the minimum cloud temperatures were higher $\left(T=-10^{\circ} \mathrm{C}\right)$ than in the spring cases. The maximum median ice concentrations observed were also higher $\left(3.35 \mathrm{~L}^{-1}\right)$. The origin of these enhanced concentrations is attributed to SIP (secondary ice production), making a direct comparison with the D10 primary IN scheme difficult. Predicted IN concentrations from D10 were found to underestimate the maximum median ice concentrations observed in this summer case (due to secondary ice production), but were in agreement with the concentrations observed near cloud top, where the ice phase is likely to represent primary heterogeneous ice nucleation. Observed ice concentrations in summer case 2 were also higher than in the previous spring cases and similar to the first summer case. The second case had higher minimum cloud temperatures than in the first summer case $\left(T=-4.3^{\circ} \mathrm{C}\right)$. Due to effect of SIP at this temperature, it was not possible to compare D10 with the concentrations of ice observed in these clouds.

\section{Discussion}

Summaries of typical profiles during each case have been presented, with microphysics data encompassing all cloud penetrations during the science flights presented as a function of altitude shown in Figs. 10, 11 and 12. Figure 10 shows the cloud liquid droplet parameters, Fig. 11 the ice crystal concentration statistics and Fig. 12 the ice mass and diameter parameters. In each case (a) is spring case 1, (b) spring case 2, (c) summer case 1 and (d) summer case 2 . The yellow lines on the ice plots (Fig. 8) show the approximate location of cloud top and cloud base altitudes deduced from liquid water content measurements exceeding $0.01 \mathrm{~g} \mathrm{~m}^{-3}$ from the CDP. It is notable that droplet concentrations (Fig. 10) are much higher in the second spring case than in the first spring case (max median values $\sim 60$ and $\sim 400 \mathrm{~cm}^{-3}$ for spring cases 1 and 2, respectively) and this is attributed to differences in aerosol concentrations. $N_{\text {drop }}$ values are similar in the two summer cases (max median values $100-150 \mathrm{~cm}^{-3}$ ) and lie between the two spring cases. The different aerosol loadings in spring cases 1 and 2 may have led to the riming indirect effect playing a role in controlling the ice phase. Case $2 \mathrm{had}$ 

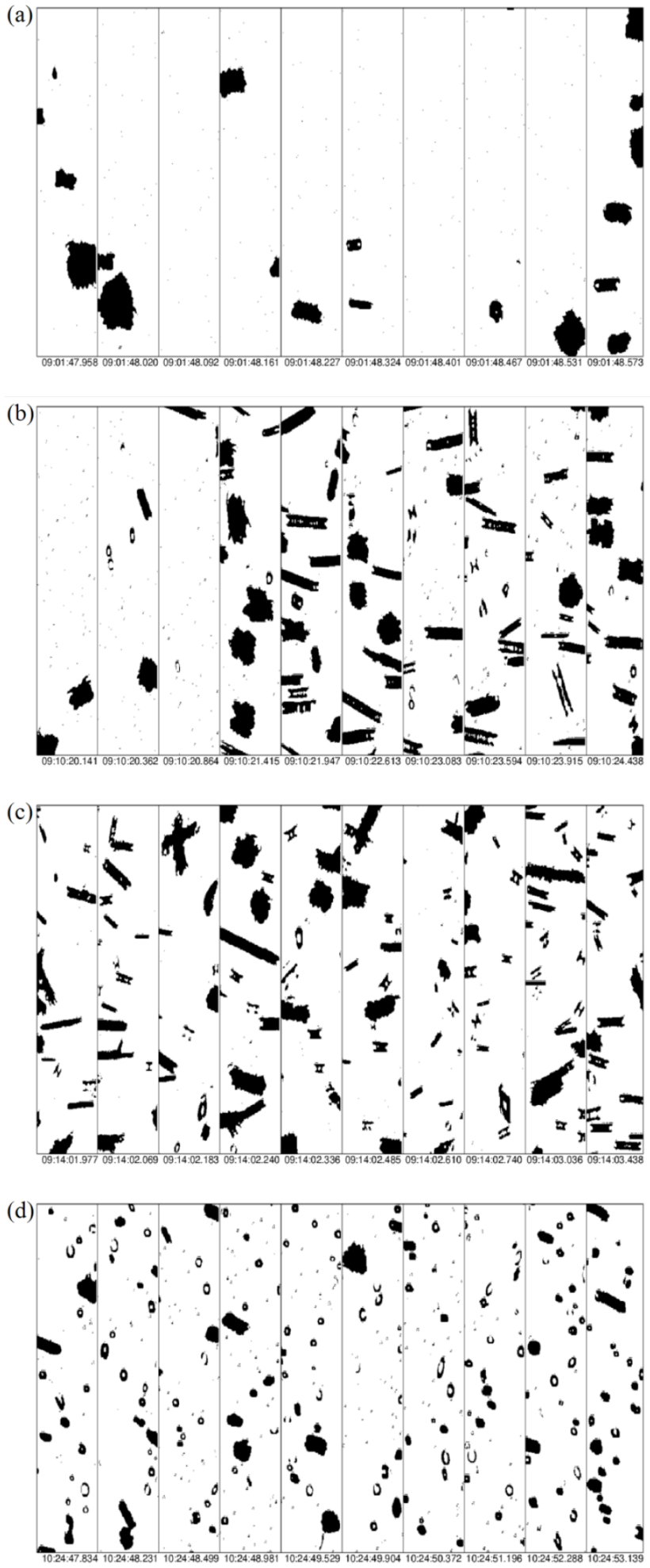

Figure 7. Images from the $2 \mathrm{D}-\mathrm{S}$ cloud probe from summer case 1 for (a) small irregular ice during $\mathrm{C} 1.2$, (b) and (c) secondary ice production during $\mathrm{C} 1.3$ and $\mathrm{C} 1.4$, respectively, and (d) ice together with drizzle during $\mathrm{C} 2$. higher aerosol loadings and increased $\mathrm{CCN}$ availability, with smaller droplet sizes (Fig. 10). In this case IWC values were also much lower than in the case 1 and it is possible that reduced riming efficiency of the smaller droplets contributed to reduced ice mass growth through riming.

During the spring cases the mixed-phase cloud layers were found to be approximately adiabatic and exhibited generally uniform increases in LWC and droplet diameter (Fig. 10) to liquid cloud tops that were observed to precipitate ice. At and above cloud top, well-defined temperature inversions were present and dew points revealed a marked dry layer just above cloud top. It was observed that cloud penetrated into the inversion layer, rather than being capped below it. On average the cloud top was seen to extend $\sim 30 \mathrm{~m}$ into the inversion layer over which range the mean temperature increase was $\sim 1.6^{\circ} \mathrm{C}$.

The ice phase is very likely to have been initiated through primary heterogeneous ice nucleation in the temperature range spanned by these clouds (approximately -10 to $-20^{\circ} \mathrm{C}$ ). Generally, low concentrations of ice crystals were observed (max median value $0.61 \mathrm{~L}^{-1}$ ) (Table 2) but with peaks up to $\sim 5-10 \mathrm{~L}^{-1}$ in both spring cases (Fig. 11). Cloud top regions consisted of small liquid droplets (median diameter $\sim 15$ and $25 \mu \mathrm{m}$ for spring cases 1 and 2, respectively) (Fig. 10a-b), together with small irregular ice crystals (Figs. 3a, 5a). In both of these cases, ice crystal diameter increased to maximum values of 530 and $660 \mu \mathrm{m}$, respectively (Fig. 12a, b). The variability in ice crystal diameter (Fig. 12a, b) shows periods where maximum ice crystal diameters increased to $\sim 2 \mathrm{~mm}$. These crystals were often comprised of a mixture of large rimed irregular particles (Figs. 3, 5) and dendritic snow crystals. Median IWC values in the spring cases reached $\sim 0.01 \mathrm{~g} \mathrm{~m}^{-3}$ (Fig. 12a, b), with peak values during case 1 of up to $\sim 0.3 \mathrm{~g} \mathrm{~m}^{-3}$ compared with $0.1 \mathrm{~g} \mathrm{~m}^{-3}$ in case 2. The highest median LWCs (Fig. 10) were observed at cloud top during spring cases, peaking at 0.3 and $0.5 \mathrm{~g} \mathrm{~m}^{-3}$ during cases 1 and 2, respectively. While these clouds were seen to be fairly uniform, time series data (Figs. 2, 4) show some of the variability in the microphysics that was observed during the science flight.

During the summer cases, the cloud layers spanned a higher temperature range $\left(-10^{\circ} \mathrm{C}<T<0^{\circ} \mathrm{C}\right)$ and welldefined temperature inversions at cloud top were less evident. There was a much greater tendency towards there being multiple cloud layers that were shallower and less well coupled. During summer case 2 a significant temperature inversion was observed (Fig. 10d) in the cloud base region, which suggested a decoupling of the boundary layer and the cloud system above. Liquid cloud top regions with few (generally $<1 \mathrm{~L}^{-1}$ ) ice crystals, formed through heterogeneous ice nucleation at these temperatures, were observed in both cases (Fig. 11c, d). LWCs in summer case 1 were lower than the spring cases (median values $<\sim 0.1 \mathrm{~g} \mathrm{~m}^{-3}$ ) but similar in shape to the uniform profiles seen in the spring cases. The second summer case had higher median LWCs (up to 


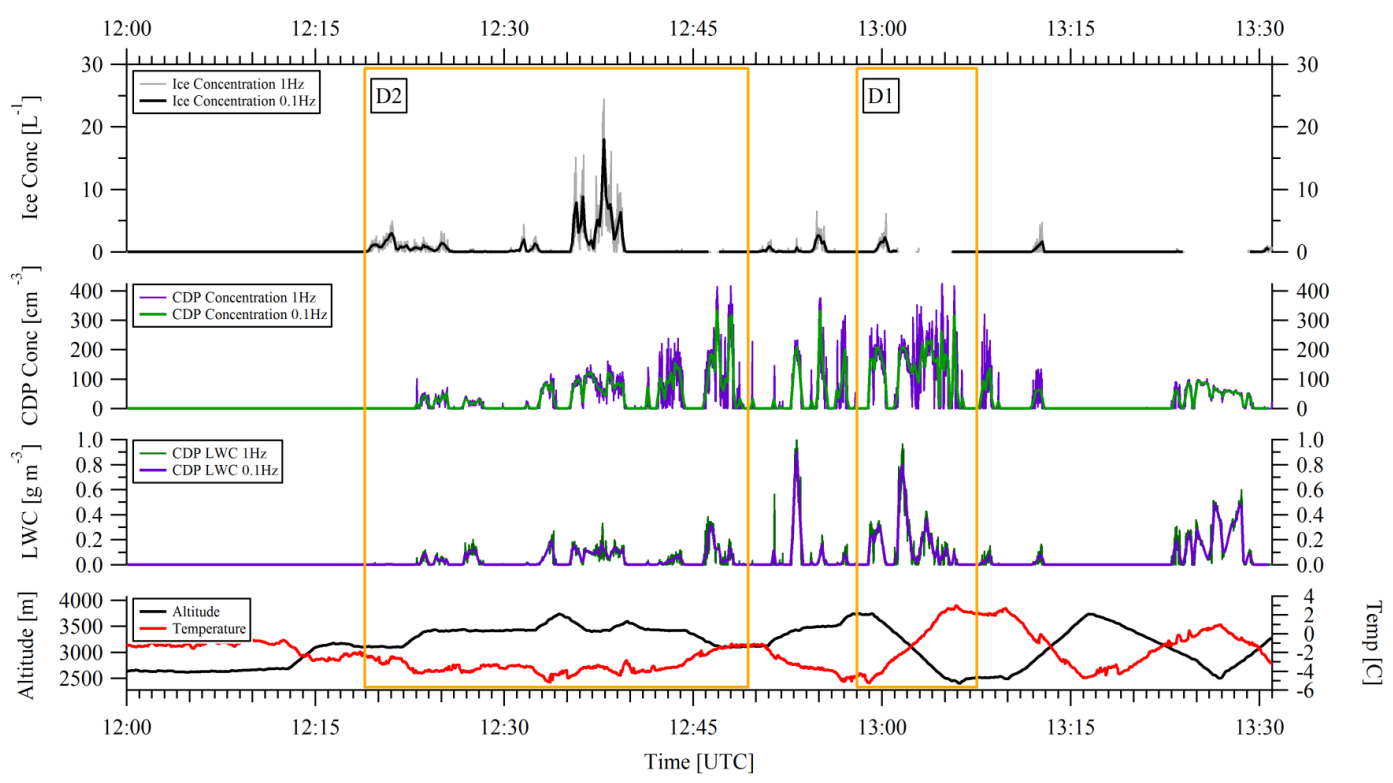

Figure 8. Microphysics time series data for summer case 2. Data includes temperature $\left({ }^{\circ} \mathrm{C}\right)$ and altitude $(\mathrm{m})$ (lower panel) together with 1 and $10 \mathrm{~s}$ data sets for CDP liquid water content $\left(\mathrm{g} \mathrm{m}^{-3}\right)$, CDP concentration $\left(\mathrm{cm}^{-3}\right)$ (middle panels), ice water content $\left(\mathrm{g} \mathrm{m}^{-3}\right)$ and ice number concentrations $\left(\mathrm{L}^{-1}\right)$ (top panel). Profile D1 is described in the Supplement.

$0.35 \mathrm{~g} \mathrm{~m}^{-3}$ ) and showed much more variability with a number of increases and decreases in median LWC values with altitude (Fig. 10d).

Median cloud top ice concentrations in summer case 1 were similar to the spring cases $\left(\sim 0.2 \mathrm{~L}^{-1}\right)$ (Fig. $11 \mathrm{~d}$ ); however, maximum median values lower down in the cloud reached $3.35 \mathrm{~L}^{-1}$ (Table 2), about a factor of 14 higher than in the spring cases. Peaks in ice number concentrations around the $-5^{\circ} \mathrm{C}$ level reached between 30 and $40 \mathrm{~L}^{-1}$. During the summer, the clouds spanned the temperature range from -3 to $-8^{\circ} \mathrm{C}$, where a well-known mechanism of secondary ice production operates through splintering during riming, the Hallett-Mossop process. The observations in this case of liquid water together with ice particles at temperatures around $-5^{\circ} \mathrm{C}$ are consistent with this process being active and enhancing ice number concentrations (Figs. 7, 9). Time series (Figs. 6, 8) showed more variation than in the spring cases. Distinct liquid cloud tops were still evident, but at lower altitudes significant variations in LWCs, droplet number concentrations and ice number concentrations were seen together with gap regions where little or no cloud was present. On a number of occasions predominantly liquid conditions were swiftly replaced by regions of high concentrations of columnar ice crystals. Some of these transitions took place over $\sim 1 \mathrm{~s}$ or horizontal distance of the order $60 \mathrm{~m}$. These rapid fluctuations were attributed to the contributions from the $\mathrm{H}-\mathrm{M}$ process. The process of glaciation through secondary enhancement of ice number concentrations is likely to have caused some of this increased variability in cloud properties too, with liquid droplets quickly being removed through depletion of liquid water by the ice phase. The cloud layers during summer case 2 spanned a higher temperature range than summer case 1 . Cloud tops were around $-4{ }^{\circ} \mathrm{C}$, and median ice number concentrations reached maximum values of $2.5 \mathrm{~L}^{-1}$, about an order of magnitude higher than in the spring cases. Time series (Fig. 8) and percentile plots (Fig. 11d) showed peaks in ice number concentrations of up to $\sim 25 \mathrm{~L}^{-1}$ and in these regions probe imagery revealed distinctive columnar ice crystals likely to have grown from splinters, produced via $\mathrm{H}-\mathrm{M}$, into habits typical of growth at these temperatures around $-4{ }^{\circ} \mathrm{C}$. In addition, the formation of high ice concentrations may have led to the dissipation of some liquid cloud regions below cloud top due to consumption of the liquid phase by ice crystals growing by vapour diffusion (i.e. ice crystal growth via the Wegener-Bergeron-Findeisen (WBF) process (Bergeron, 1935). This is consistent with the observed summer clouds being more broken than the clouds observed during spring. However, as discussed in the introduction, it is also recognised that cloud-radiation interactions may lead to the separation of cloud layers during the Arctic summer.

Comparison of the observed $N_{\text {ice }}$ with the D10 parameterisation of primary ice nuclei numbers revealed that during the spring case 1 maximum median $N_{\text {ice }}$ was lower than the primary IN concentrations predicted by D10, but similar in spring case 2. Peaks in $N_{\text {ice }}$ were much higher than the D10 IN predictions, by an amount depending on the aerosol measurement period used as input to D10 (Table 2). Our observations show deviations in the ice concentrations of as much as an order of magnitude compared with the D10 IN prediction. The variation in ice number concentrations observed in 
(a)

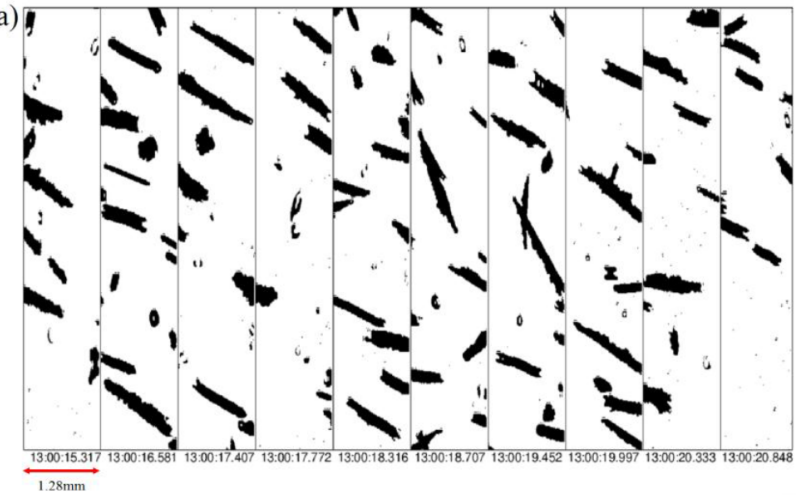

(b)

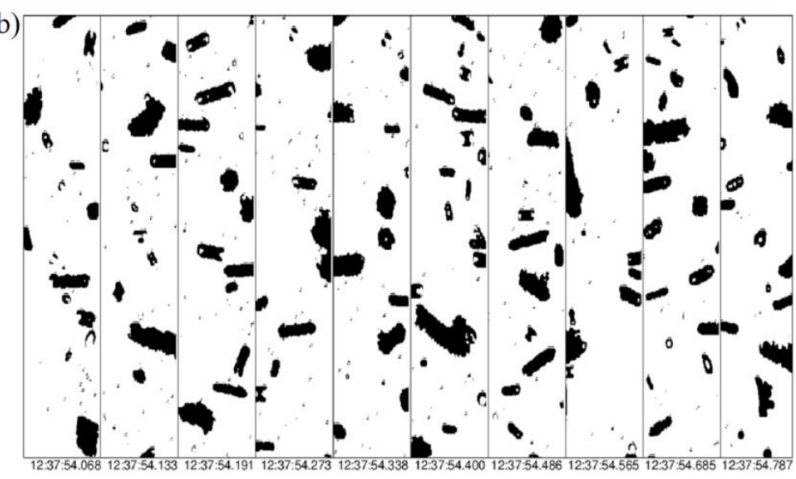

(c)

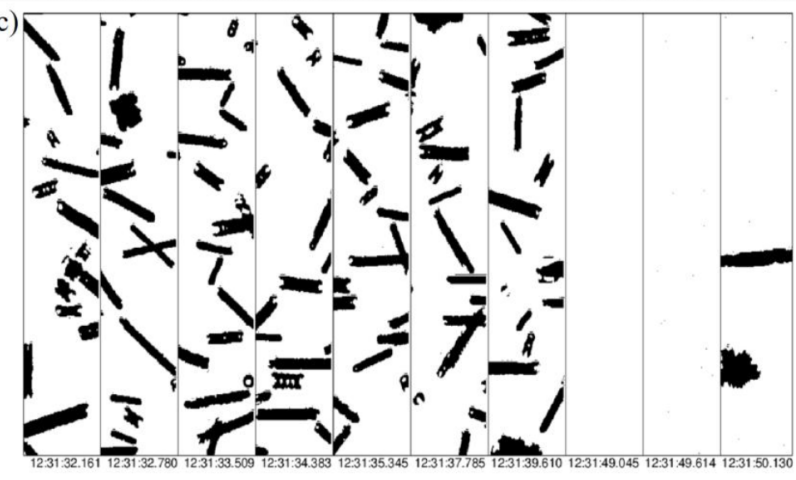

(d)

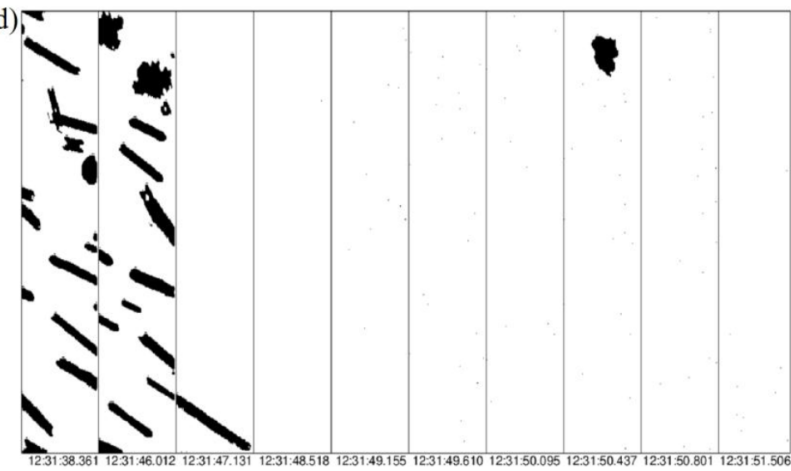

Figure 9. 2D-S cloud probe imagery for summer case 2 showing (a) columnar ice during D1, (b) images of columns together with liquid during D2 and swift transitions between (c) glaciated and (d) liquid phases during D2.
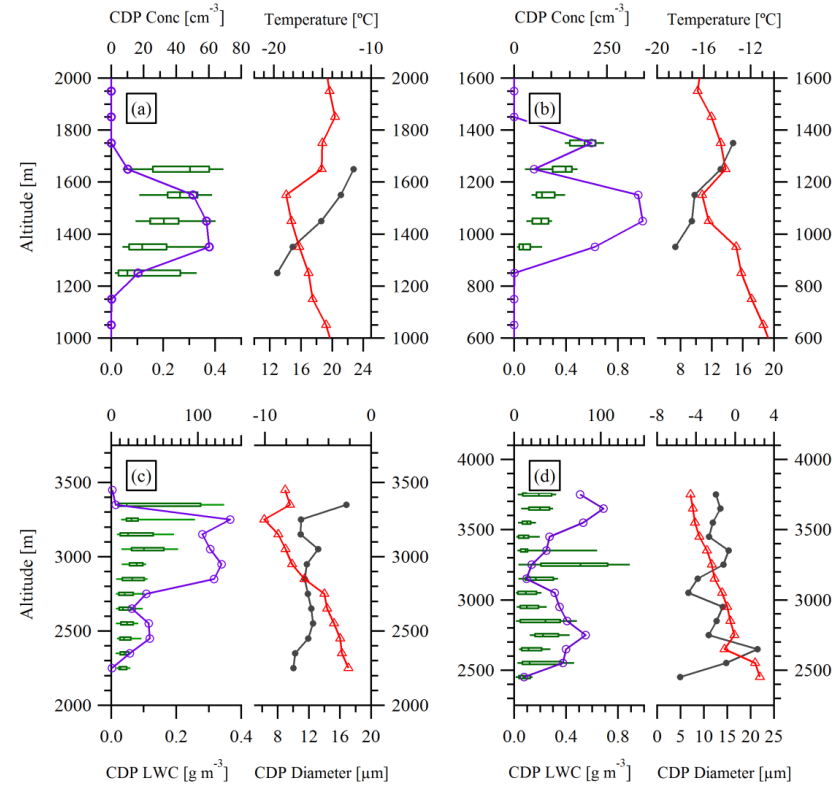

Figure 10. Percentile plots (50th, 25th, 75th percentiles, whiskers to 10 and $90 \%$ ) as a function of altitude for LWC from CDP (green), and median droplet number concentration (purple), median droplet diameter (grey) and median temperature (red). Data are averaged over $100 \mathrm{~m}$ deep layers. (a)-(d) are for spring case 1 , spring case 2 , summer case 1 and summer case 2 , respectively.
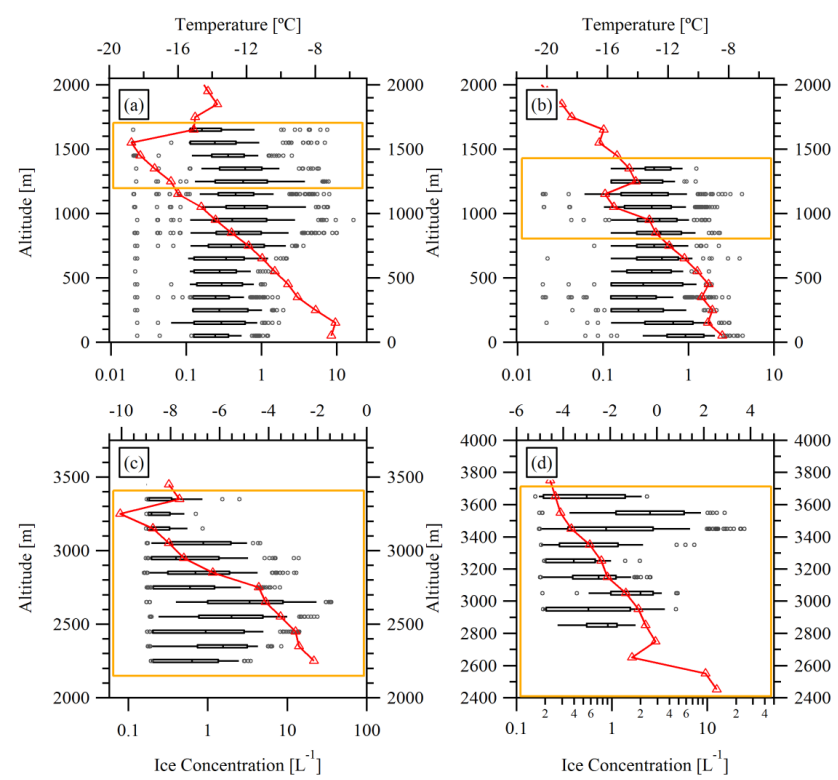

Figure 11. Box and whisker plots with 50th, 25th, 75th percentiles, whiskers to 10 and $90 \%$ and outliers between 95 and $100 \%$ as a function of altitude for ice number concentrations (black) and median temperature (red) (a-d and altitude averages as in Fig. 10). The box in yellow provides an indication of the full extent of cloud layers investigated. (a)-(d) are for spring case 1 , spring case 2 , summer case 1 and summer case 2 , respectively. 

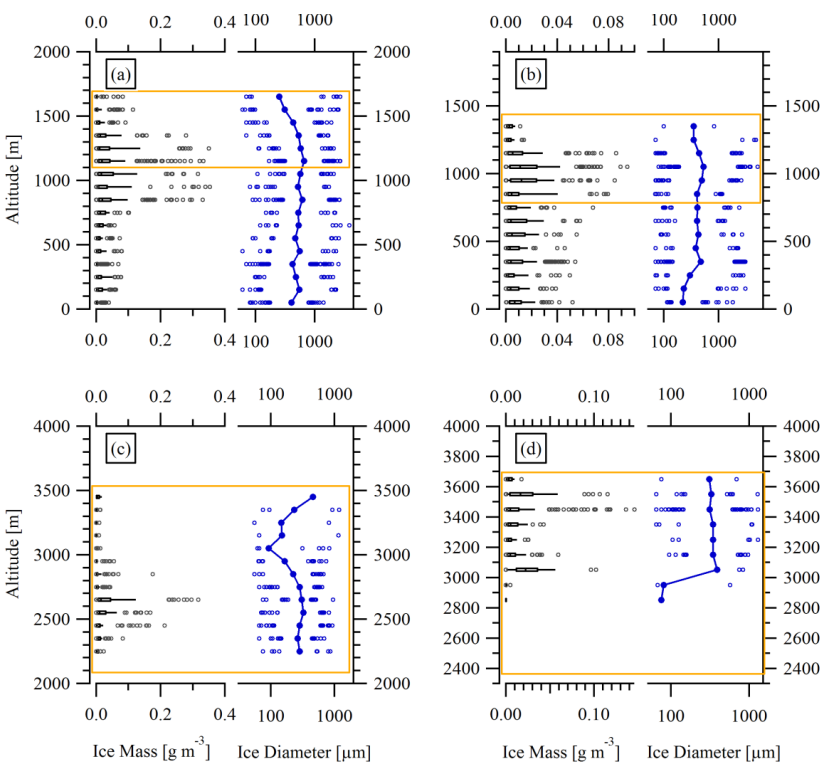

Figure 12. Box and whisker plots with 50th, 25th, 75th percentiles, whiskers to 10 and $90 \%$ and outliers between 95 and $100 \%$ as a function of altitude for ice mass (black) and median ice crystal diameter with outliers between 95 and $100 \%$ (blue) ((a)-(d) and altitude averages as in Fig. 10). The box in yellow provides an indication of the full extent of cloud layers investigated. (a)-(d) are for spring case 1 , spring case 2 , summer case 1 and summer case 2, respectively.

the spring cases could be explained by the variability in observed IN values presented in the DeMott et al. (2010) paper.

In the summer cases the enhancement of $N_{\text {ice }}$ through the $\mathrm{H}-\mathrm{M}$ process made a realistic comparison difficult. Despite this difficulty, the first summer case had cloud top temperatures that were just outside the $\mathrm{H}-\mathrm{M}$ temperature zone $\left(-10^{\circ} \mathrm{C}\right)$ and the median $N_{\text {ice }}$ in this region was $\sim 0.2 \mathrm{~L}^{-1}$, which is within a factor of 2 of the values predicted by D10 (Table 2). At lower altitudes the increase in cloud temperatures allowed rime splintering to enhance concentrations to above what would be expected via primary heterogeneous ice nucleation. In the second summer case cloud top temperatures were higher $\left(-4^{\circ} \mathrm{C}\right)$, and enhancement of the ice crystal number concentrations through SIP prevented observations of any first ice by primary nucleation being made. Ice crystal number concentrations were thus enhanced to values above what was predicted by D10 throughout the depth of the cloud.

The microphysical structure of the spring and summer stratocumulus layers was found to be consistent with previous observations of Arctic clouds. We observed generally low droplet number concentrations that were enhanced during incursions of higher aerosol loadings, similar to findings by Verlinde et al. (2007). During spring cases, LWCs and liquid droplet size increased uniformly to cloud top, however during summer months the vertical structure of cloud layers was more variable (e.g. Hobbs and Rangno, 1998). During spring cases in particular, liquid cloud tops at distinct temperature inversions continually precipitated low concentrations of ice into the cloud below, which has been observed previously in the Arctic. Rogers et al. (2001) made airborne measurements of IN in thin, low-level Arctic clouds in the same temperature range as our spring cases. They found evidence for a few IN in these clouds with concentrations of ice that were similar to the observations presented here.

During the Arctic summer, Hobbs and Rangno (1998) observed generally higher ice concentrations with columnar and needle ice crystals in concentrations of "tens per litre" where stratocumulus cloud top temperatures were between -4 and $-9^{\circ}$ C. Rangno and Hobbs (2001) found that high ice particle concentrations were common during late spring and summer in the Arctic. Despite the presence of some columnar ice, many of the crystals were irregular in shape, and it was suggested that shattering of freezing drops $>50 \mu \mathrm{m}$ or the fragmentation of fragile ice may have contributed to the high concentrations. Although we have not performed habit classification analysis on our data set the images suggest that the ice phase in summer cases was dominated by columnar ice, with evidence of a small number of irregular ice particles. Previous laboratory studies found that larger droplets were necessary to initiate rime splintering (Mossop, 1980) and Hobbs and Rangno confirm that in the cases they studied a threshold droplet size of $28 \mu \mathrm{m}$ was required, below which secondary ice production did not take place. In the limited summer cases we had in the appropriate temperature range, secondary ice production took place in the presence of concentrations of liquid droplets over this threshold size.

The summer cases we observed contained median values of $N_{\text {ice }}$ that were 4-6 times greater than we observed in the spring cases. In both summer cases where the H-M process was active droplet sizes were similar, and we did not find any evidence for a thermodynamic indirect effect leading to differences in the efficiency of secondary ice production in summer cases. Changes in aerosol concentrations and composition have been suggested as a possible factor in explaining previous observations of the glaciation of Arctic clouds at different temperatures (Curry et al., 1996). During spring case 2 higher concentrations of aerosol were observed when compared to spring case 1 . Droplet number concentrations were also much higher in spring case 2, generally $300-400 \mathrm{~cm}^{-3}$ in comparison to spring case 1 where concentrations were generally $\sim 50-100 \mathrm{~cm}^{-3}$. Despite this, no significant difference was observed in the ice number concentrations. However, it should be noted that despite the higher total concentrations, the population of aerosol $>0.5 \mu \mathrm{m}$ was not significantly enriched in spring case 2 compared to the spring case 1. D10 has a dependency only on this portion of the aerosol size distribution, which may explain the similar primary ice number concentrations for both spring case studies. Although we did not make any direct measurements of IN, in both Arctic spring cases and Antarctic cases primary 
Table 3. Table reproduced from Grosvenor et al. (2012) reporting observations of ice number concentrations, aerosol concentrations $>0.5 \mu \mathrm{m}$ and primary IN predictions using the D10 parameterisation.

\begin{tabular}{lrrrrrr}
\hline Flight & $\begin{array}{r}\text { Mean ice conc } \\
\left(\mathrm{L}^{-1}\right)\end{array}$ & $\begin{array}{r}\text { Max } \pm \mathrm{SD}(60 \mathrm{~s}) \\
\text { ice conc }\left(\mathrm{L}^{-1}\right)\end{array}$ & $\begin{array}{r}\text { Temp of max } \\
\text { conc }\left({ }^{\circ} \mathrm{C}\right)\end{array}$ & $\begin{array}{r}\text { Max RH for } \\
\text { aerosol }(\%)\end{array}$ & $\begin{array}{r}\text { Observed aerosol } \\
\text { conc }\left(\mathrm{cm}^{-3}\right)\end{array}$ & $\begin{array}{r}\text { Predicted IN } \\
\text { value }\left(\mathrm{L}^{-1}\right)\end{array}$ \\
\hline \multicolumn{7}{c}{ Cloud layers over Larsen C } \\
\hline $99-\mathrm{i} 4$ & $0.007 \pm 0.002$ & $0.017 \pm 0.007 / 0.005$ & -13.8 & 50 & $0.33 \pm 0.05$ & $0.25 \pm 0.26 / 0.23$ \\
$99-\mathrm{i} 5$ & $0.007 \pm 0.001$ & $0.020 \pm 0.007 / 0.004$ & -16.5 & 50 & $0.33 \pm 0.05$ & $0.41 \pm 0.44 / 0.39$ \\
$104-\mathrm{i} 3$ & $0.008 \pm 0.002$ & $0.012 \pm 0.005 / 0.003$ & -17.7 & 40 & $0.15 \pm 0.03$ & $0.35 \pm 0.38 / 0.31$ \\
$104-\mathrm{i} 4$ & $0.011 \pm 0.002$ & $0.032 \pm 0.010 / 0.007$ & -13.4 & 60 & $0.15 \pm 0.03$ & $0.17 \pm 0.18 / 0.16$ \\
\hline \multicolumn{7}{c}{ Hallett-Mossop zone ice } \\
$100-\mathrm{i} 1$ & $0.52 \pm 0.02$ & $1.28 \pm 0.06 / 0.38$ & -0.7 & 75 & $0.42 \pm 0.05$ & $1.9 \times 10^{-5}$ \\
$100-\mathrm{i} 2$ & $1.14 \pm 0.02$ & $3.44 \pm 0.11 / 1.01$ & -2.3 & 75 & $0.42 \pm 0.05$ & $9.1 \times 10^{-4}$ \\
$100-\mathrm{i} 3$ & $1.47 \pm 0.02$ & $6.26 \pm 0.15 / 1.78$ & -4.3 & 75 & $0.42 \pm 0.05$ & 0.007 \\
$100-\mathrm{i} 4$ & $0.90 \pm 0.02$ & $4.77 \pm 0.12 / 1.28$ & -5.9 & 75 & $0.42 \pm 0.05$ & 0.019 \\
$100-\mathrm{i} 5$ & $0.05 \pm 0.01$ & $0.06 \pm 0.01 / 0.01$ & -5.6 & 75 & $0.42 \pm 0.05$ & 0.016 \\
$100-\mathrm{i} 6$ & $0.040 \pm 0.008$ & $0.07 \pm 0.01 / 0.03$ & -5.2 & 75 & $0.42 \pm 0.05$ & 0.013 \\
$104-\mathrm{i} 5$ & $0.098 \pm 0.007$ & $0.37 \pm 0.03 / 0.12$ & -2.3 & 94 & $0.1 \pm 0.05$ & $8.3 \times 10^{-4}$ \\
$104-\mathrm{i} 6$ & $0.33 \pm 0.01$ & $2.7 \pm 0.01 / 0.63$ & -2.3 & 94 & $0.1 \pm 0.05$ & $8.3 \times 10^{-5}$ \\
\hline
\end{tabular}

heterogeneous ice nucleation was identified as the dominant source of ice. It is very likely that the higher concentrations of ice in the Arctic cases when compared to the Antarctic were therefore due to increasing IN availability, which is consistent with the glaciation indirect effect.

Grosvenor et al. (2012) studied stratocumulus clouds in the Antarctic over the Larsen C Ice Shelf. These observations contained periods where temperatures were comparable to those in the spring cases studied here. The lower layers of Antarctic cloud were also reported to contain higher concentrations of ice produced via the $\mathrm{H}-\mathrm{M}$ process, similar to the summer cases that we have discussed. A summary of some of the measurements reported from the Antarctic in Grosvenor et al. (2012) can be found in Table 3. Measurements of cloud regions outside the $\mathrm{H}-\mathrm{M}$ temperature zone revealed very low ice number concentrations, with maximum values about 2 orders of magnitude lower than those observed in the spring cases reported here. Aerosol concentrations from a CAS probe (similar to the one deployed in this study) reported generally lower concentrations of aerosol particles $D_{\mathrm{p}}>0.5 \mu \mathrm{m}$. The D10 IN predictions in the Antarctic were reported to compare better with maximum, rather than mean ice values. A similar result was found in this study where predicted primary IN values were greater than observed median values. However, when comparing with peak ice concentration values the scheme significantly underpredicted these. Grosvenor et al. (2012) discussed the possibility that due to the D10 parameterisation being based on mean IN concentrations from many samples, the finding that IN predictions compared well with the maximum values rather than mean values may suggest the scheme was over predicting IN concentrations generally in the Antarctic (for these particular cases at least). In the H-M layer in the Antarctic over Larsen $\mathrm{C}$, ice crystal number concentrations were found to be higher than those observed in colder temperature regimes (not spanning the $\mathrm{H}-\mathrm{M}$ temperature range), in keeping with the findings from the Arctic presented this paper. However the concentrations produced by the $\mathrm{H}-\mathrm{M}$ process in the Antarctic were generally only a few per litre, approximately an order of magnitude lower than those observed during the summer cases in the Arctic.

\section{Conclusions}

Detailed microphysics measurements made in Arctic stratocumulus cloud layers during the early spring and summer have been presented.

- Two spring and two summer cases were presented. The cloud layers during summer cases spanned a warmer temperature range $\left(\sim 0^{\circ} \mathrm{C} \geq T>-10^{\circ} \mathrm{C}\right)$ than in spring (generally $\sim-10^{\circ} \mathrm{C} \geq T>-20^{\circ} \mathrm{C}$ ).

- Spring case 2 had significantly higher aerosol concentrations $\left(\sim 300-400 \mathrm{~cm}^{-3}\right)$ compared to the first spring case $\left(\sim 50-100 \mathrm{~cm}^{-3}\right)$. Despite this difference, ice number concentrations were found to be similar in both spring cases, suggesting the source of the increased aerosol concentrations was not providing additional IN that were efficient over the temperature range of $-10^{\circ} \mathrm{C}>T>-20^{\circ} \mathrm{C}$.

- In the spring cases, cloud layers appeared more uniform with steady increases in LWC and cloud droplet size to cloud top, where low concentrations $\left(<1 \mathrm{~L}^{-1}\right)$ 
of ice were frequently observed to precipitate through the depth of the cloud layer. The small irregular particles observed at cloud top grew to a median diameter $\sim 500 \mu \mathrm{m}$ in both cases with peaks in diameter $>1000 \mu \mathrm{m}$ as the crystals descended through the cloud. 2D-S imagery revealed the dominant growth habit to be dendritic in nature. The summer cases consisted of multiple cloud layers that were observed to be more variable than in the spring. However, liquid cloud top regions were still evident and ice was again observed to precipitate into the cloud layers below.

- The maximum median ice number concentrations observed within cloud layers during the summer cases were approximately a factor of 5 (or more) higher than in the spring cases. This enhancement in the ice number concentrations is attributed to the contribution of secondary ice production through the $\mathrm{H}-\mathrm{M}$ process.

- This finding suggests that low level summer stratocumulus clouds situated in the $\mathrm{H}-\mathrm{M}$ temperature zone in the Arctic may contain significantly higher ice number concentrations than in spring clouds due to the temperature range of the former spanning the active $\mathrm{H}-\mathrm{M}$ temperature zone.

- Predicted values from the DeMott et al. (2010) scheme of primary ice nuclei, using aerosol measurements obtained during the science flights as input, tended to overpredict IN concentrations compared to the observed maximum median ice crystal number concentrations during the spring, but underpredict IN when compared to peak ice crystal concentrations. This variation can be attributed to uncertainties in the application of the DeMott scheme. During the summer cases, due to contributions from secondary ice production, the scheme predicted significantly lower values of ice particles than those observed.

- We found some support for the riming indirect effect when comparing our spring cases. In spring case 2 higher aerosol loadings and smaller droplets were observed and ice water contents were lower than in spring case 1 (where aerosol concentrations were much lower). It is possible the smaller droplets in case 2 reduced the riming efficiency leading to lower ice mass values.

- Grosvenor et al. (2012) observed lower concentrations of aerosol $>0.5 \mu \mathrm{m}$ in the Antarctic when compared to similar measurements made in the Arctic. They found that IN predictions using D10 agreed better with their observed peak ice concentration values rather than their maximum mean values. They measured approximately an order of magnitude lower primary ice concentrations in summer Antarctic clouds than in our spring Arctic cases, but did observe enhancement through SIP in warmer cloud layers where concentrations increased to a few per litre. These were still about an order of magnitude less than the enhanced concentrations observed in the Arctic summer cases presented here, but were similar to the peak values observed in spring cases over the Arctic (where no SIP was observed).

\section{The Supplement related to this article is available online at doi:10.5194/acp-15-3719-2015-supplement.}

Acknowledgements. This project was supported by the Natural Environment Research Council under grant NE/1028296/1. Airborne data were obtained using the BAe-146-301 Atmospheric Research Aircraft [ARA] flown by Directflight Ltd and managed by the Facility for Airborne Atmospheric Measurements (FAAM), which is a joint entity of the Natural Environment Research Council (NERC) and the Met Office.

Edited by: E. Weingartner

\section{References}

ACIA.: Arctic Climate Impact Assessment, Cambridge University Press, 1042 pp., 2005.

Baker, B. and Lawson, P.: Improvement in Determination of Ice Water Content from Two-Dimensional Particle Imagery. Part I: Image-to-Mass Relationships, J. Appl. Meteorol. Climatol., 45, 1282-1290, 2006.

Baumgardner, D., Jonsson, H., Dawson, W., O'Connor, D., and Newton, R.: The cloud, aerosol and precipitation spectrometer: a new instrument for cloud investigations, Atmos. Res., 59-60, 251-264, doi:10.1016/S0169-8095(01)00119-3, 2001.

Bergeron, T.: On the physics of clouds and precipitation, Proces Verbaux de l'Association de Météorologie, International Union of Geodesy and Geophysics, 156-178, 1935.

Brown, P. and Francis, P.: Improved measurements of the ice water content in cirrus using a total-water probe, J. Atmos. Ocean. Tech, 12, 410-414, 1995.

Callaghan, T. V., Johansson, M., Key, J., Prowse, T., Ananicheva, M., and Klepikov, A.: Feedbacks and Interactions: From the Arctic Cryosphere to the Climate System, Ambio, 40, 75-86, doi:10.1007/s13280-011-0215-8, 2012.

Crosier, J., Bower, K. N., Choularton, T. W., Westbrook, C. D., Connolly, P. J., Cui, Z. Q., Crawford, I. P., Capes, G. L., Coe, H., Dorsey, J. R., Williams, P. I., Illingworth, A. J., Gallagher, M. W., and Blyth, A. M.: Observations of ice multiplication in a weakly convective cell embedded in supercooled mid-level stratus, Atmos. Chem. Phys., 11, 257-273, doi:10.5194/acp-11-257-2011, 2011.

Crosier, J., Choularton, T. W., Westbrook, C. D., Blyth, A. M., Bower, K. N., Connolly, P. J., Dearden, C., Gallagher, M. W., Cui, Z., and Nicol, J. C.: Microphysical properties of cold frontal rainbands, Q. J. Roy. Meteorol. Soc., 140, 1257-1268, doi:10.1002/qj.2206, 2013. 
Curry, J. A.: Interactions among aerosols, clouds, and climate of the Arctic Ocean, Sci. Total Environ., 160, 777-791, 1995.

Curry, J. A., Rossow, W. B., Randall, D., and Schramm, J. L.: Overview of Arctic Cloud and Radiation Characteristics, J. Clim., 9, 1731-1764, 1996.

Curry, J. A., Pinto, J. O., Benner, T., and Tschudi, M.: Evolution of the cloudy boundary layer during the autumnal freezing of the Beaufort Sea, 102, 13851-13860, doi:10.1029/96JD03089, 1997.

DeMott, P. J., Prenni, A. J., Liu, X., Kreidenweis, S. M., Petters, M. D., Twohy, C. H., Richardson, M. S., Eidhammer, T., and Rogers, D. C.: Predicting global atmospheric ice nuclei distributions and their impacts on climate, P. Natl. Acad. Sci. USA, 107, 1121711222, doi:10.1073/pnas.0910818107, 2010.

Field, P. R., Heymsfield, A. J., and Bansemer, A.: Shattering and particle interarrival times measured by optical array probes in ice clouds, J. Atmos. Ocean. Tech., 23, 1357-1371, doi:10.1175/JTECH1922.1, 2006.

Grosvenor, D. P., Choularton, T. W., Lachlan-Cope, T., Gallagher, M. W., Crosier, J., Bower, K. N., Ladkin, R. S., and Dorsey, J. R.: In-situ aircraft observations of ice concentrations within clouds over the Antarctic Peninsula and Larsen Ice Shelf, Atmos. Chem. Phys., 12, 11275-11294, doi:10.5194/acp-12-11275-2012, 2012.

Hallett, J. and Mossop, S. C.: Production of secondary ice crystals during the riming process, Nature, 249, 26-28, 1974.

Herman, G. and Goody, R.: Formation and Persistence of Summertime Arctic Stratus Clouds, J. Atmos. Sci., 33, 1537-1553, doi:10.1175/1520-0469(1976)033<1537:FAPOSA>2.0.CO;2, 1976.

Hobbs, P. V. and Rangno, A. L.: Microstructures of low and middlelevel clouds over the Beaufort Sea, Q. J. Roy. Meteorol. Soc., 124, 2035-2071, doi:10.1002/qj.49712455012, 1998.

Intrieri, J. M.: An annual cycle of Arctic surface cloud forcing at SHEBA, J. Geophys. Res., 107, 8039, doi:10.1029/2000JC000439, 2002.

IPCC.: Climate Change 2007: Synthesis Report. Contribution of Working Groups I, II and III to the Fourth Assessment Report of the Intergovernmental Panel on Climate Change, edited by: Core Writing Team, Pachauri, R. K., and Reisinger, A., IPCC, Geneva, Switzerland, 104 pp., 2007.

IPCC.: Climate Change 2014: Synthesis Report. Contribution of Working Groups I, II and III to the Fifth Assessment Report of the Intergovernmental Panel on Climate Change, edited by: Core Writing Team, Pachauri, R. K. and Meyer, L. A., IPCC, Geneva, Switzerland, 151 pp., 2014.

Jackson, R. C., McFarquhar, G. M., Korolev, A. V., Earle, M. E., Liu, P. S. K., Lawson, R. P., Brooks, S., Wolde, M., Laskin, A., and Freer, M.: The dependence of ice microphysics on aerosol concentration in arctic mixed-phase stratus clouds during ISDAC and M-PACE, J. Geophys. Res., 117, D15207, doi:10.1029/2012JD017668, 2012.

Jayaweera, K. O. L. F. and Ohtake, T.: Concentration of ice crystals in Arctic stratus clouds, J. Rech. Atmos., 7, 199-207, 1973.

Kahl, J. D.: Characteristics of the low-level temperature inversion along the Alaskan Arctic coast, Int. J. Climatol., 10, 537-548, 1990.

Korolev, A. V., Emery, E. F., Strapp, J. W., Cober, S. G., Isaac, G. A., Wasey, M., and Marcotte, D.: Small ice particles in tropospheric clouds: fact or artifact?, B. Am. Meteorol. Soc., 92, 967-973, doi:10.1175/2010BAMS3141.1, 2011.

Korolev, A. V., Emergy, E., and Creelman, K.: Modification and Tests of Particle Probe Tips to Mitigate Effects of Ice Shattering, J. Atmos. Ocean. Tech., 30, 690-708, 2013

Lance, S., Brock, C. A., Rogers, D., and Gordon, J. A.: Water droplet calibration of the Cloud Droplet Probe (CDP) and inflight performance in liquid, ice and mixed-phase clouds during ARCPAC, Atmos. Meas. Tech., 3, 1683-1706, doi:10.5194/amt3-1683-2010, 2010.

Lance, S., Shupe, M. D., Feingold, G., Brock, C. A., Cozic, J., Holloway, J. S., Moore, R. H., Nenes, A., Schwarz, J. P., Spackman, J. R., Froyd, K. D., Murphy, D. M., Brioude, J., Cooper, O. R., Stohl, A., and Burkhart, J. F.: Cloud condensation nuclei as a modulator of ice processes in Arctic mixed-phase clouds, Atmos. Chem. Phys., 11, 8003-8015, doi:10.5194/acp-11-80032011, 2011.

Lawson, P. R.: The 2D-S (stereo) probe: design and preliminary tests of a new airborne high-speed, high resolution particle imagine probe, J. Atmos. Ocean. Tech., 23, 1462-1477, 2006.

Lohmann, U. and Feichter, J.: Global indirect aerosol effects: a review, Atmos. Chem. Phys., 5, 715-737, doi:10.5194/acp-5-7152005, 2005.

McInnes, K. and Curry, J.: Modelling the mean and turbulent structure of the summertime Arctic cloudy boundary layer, Bound.Lay. Meteorol., 73, 125-143, 1995.

Mossop, S. C.: The mechanism of ice splinter production during riming, Geophys. Res. Lett., 7, 167-169, 1980

Overland, J. E. and Wang, M.: When will the summer Arctic be nearly sea ice free?, Geophys. Res. Lett., 40, 2097-2101, doi:10.1002/grl.50316, 2013.

Parkinson, C. L. and Comiso, J. C.: On the 2012 record low Arctic sea ice cover: Combined impact of preconditioning and an August storm, Geophys. Res. Lett., 40, 1356-1361, doi:10.1002/grl.50349, 2013.

Rangno, A. L. and Hobbs, P. V.: Ice particles in stratiform clouds in the Arctic and possible mechanisms for the production of high ice concentrations, J. Geophys. Res., 106, 15065, doi:10.1029/2000JD900286, 2001.

Rogers, D. C., DeMott, P. J., and Kreidenweis, S. M.: Airborne measurements of tropospheric ice-nucleating aerosol particles in the Arctic spring, J. Geophys. Res., 106, 15053, doi:10.1029/2000JD900790, 2001.

Rosenberg, P. D., Dean, A. R., Williams, P. I., Dorsey, J. R., Minikin, A., Pickering, M. A., and Petzold, A.: Particle sizing calibration with refractive index correction for light scattering optical particle counters and impacts upon PCASP and CDP data collected during the Fennec campaign, Atmos. Meas. Tech., 5, 1147-1163, doi:10.5194/amt-5-1147-2012, 2012.

Tsay, S. and Jayaweera, K.: Physical characteristics of Arctic stratus clouds, J. Clim. Appl. Meteorol., 23, 584-596, 1984.

Uttal, T., Curry, J. A., McPhee, M. G., Perovich, D. K., Moritz, R. E., Maslanik, J. A., Guest, P. S., Stern, H. L., Moore, J. A., Turenne, R., Heiberg, A., Serreze, M. C., Wylie, D. P., Persson, P. O. G., Paulson, C. A., Halle, C., Morrison, J. H., Wheeler, P. A., Makshtas, A., Welch, H., Shupe, M. D., Intrieri, J. M., Stamnes, K., Lindsey, R. W., Pinkel, R., Pegau, W. S., Stanton, T. P., and Grenfeld, T. C.: Surface heat budget of the Arctic ocean, B. Am. Meteorol. Soc., 83, 255-275, 2002. 
Verlinde, J., Harrington, J. Y., Yannuzzi, V. T., Avramov, A., Greenberg, S., Richardson, S. J., Bahrmann, C. P., McFarquhar, G. M., Zhang, G., Johnson, N., Poellot, M. R., Mather, J. H., Turner, D. D., Eloranta, E. W., Tobin, D. C., Holz, R., Zak, B. D., Ivey, M. D., Prenni, A. J., DeMott, P. J., Daniel, J. S., Kok, G. L., Sassen, K., Spangenberg, D., Minnis, P., Tooman, T. P., Shupe, M., Heymsfield, A. J., and Schofield, R.: The Mixed-Phase Arctic Cloud Experiment, B. Am. Meteorol. Soc., 88, 205-221, doi:10.1175/BAMS-88-2-205, 2007.
Walsh, J. E., Chapman, W. L., and Portis, D. H.: Arctic Cloud Fraction and Radiative Fluxes in Atmospheric Reanalyses, J. Climate, 22, 2316-2334, doi:10.1175/2008JCLI2213.1, 2009. 